\title{
Marine Shielings in Medieval Norse Greenland
}

\author{
Christian Koch Madsen
}

\begin{abstract}
The Norse that settled Greenland between ca. AD 985 and 1450 were sedentary agropastoralists that combined farming with hunting and organized after a North Atlantic socioeconomic model. Research of the last 40 years has emphasized the great and increasing importance of marine resources for both the Greenland Norse local subsistence economy and long-distance trade. However, the archaeological sites and features associated with the marine economy have not been systematically investigated. This study reviews documentary records and archaeological site evidence of medieval Norse marine-resource use in Greenland on local to regional scales. Contextualizing this evidence within a locally adjusted, Arctic version of a general North Atlantic settlement and land-use model, and applying a formalized interpretational framework, the study implies the existence of at least four types of seasonally occupied, specialized satellite sites related to marine-resource use-sites that tentatively may be labeled "marine shielings." Marine shielings likely served to improve the expediency and safety of Norse marine-resource use on both Greenland's west and east coasts, where marine hunting appears to have been a frequent, specialized, and cooperative activity.
\end{abstract}

Around AD 1000, Norse farmer-hunters founded two settlements on Greenland's west coast (Fig. 1): the Eystribyggð (Eastern Settlement) in South Greenland and the smaller Vestribyggð (Western Settlement) in the Nuuk and Ameralik fjord systems (Arneborg 2004). These settlements formed complex systems of farmsteads and satellite sites with a total maximum population of 2000-3000 (Lynnerup 1998; Madsen 2014b). For ca. 450 years, the Norse Greenlanders successfully sustained this westernmost secluded Arctic node in European cultural and economic networks bridging half the world. However, for still unresolved reasons, the Norse settlements eventually declined and disappeared: the Vestribyggð before AD 1400 and the Eystribyggð by AD 1450 (Arneborg et al. 2012b).

Agropastoral, medieval Norse settlement was, as everywhere in the North Atlantic, organized around the production from and yearly upkeep of animal husbandry consisting of cattle, pig, sheep, goats. However, research of the last 40 years has emphasized the great importance of wild resources for the Greenland Norse subsistence and trade economy. Archaeofauna consistently display $40-85 \%$ wild species across all types of farmsteads, including those in the hinterland, and exhibit a clear trend of increasing percentages over

National Museum of Denmark, Department of Middle Ages, Renaissance and Numismatics, Frederiksholms Kanal 12, 1220 København K, Denmark; christian.koch.madsen@natmus.dk

Greenland National Museum and Archives, Hans Egedesvej 8, Box 145, 3900 Nuuk, Greenland; christian@natmus.gl

ARCTIC ANTHROPOLOGY, Vol. 56, No. 1, pp. 119-159, 2019 ISSN 0066-6939

(C) 2019 by the Board of Regents of the University of Wisconsin System

This open access article is distributed under the terms of the CC-BY-NC-ND license

(http://creativecommons.org/licenses/by-nc-nd/4.0) and is freely available online at: http://aa.uwpress.org 


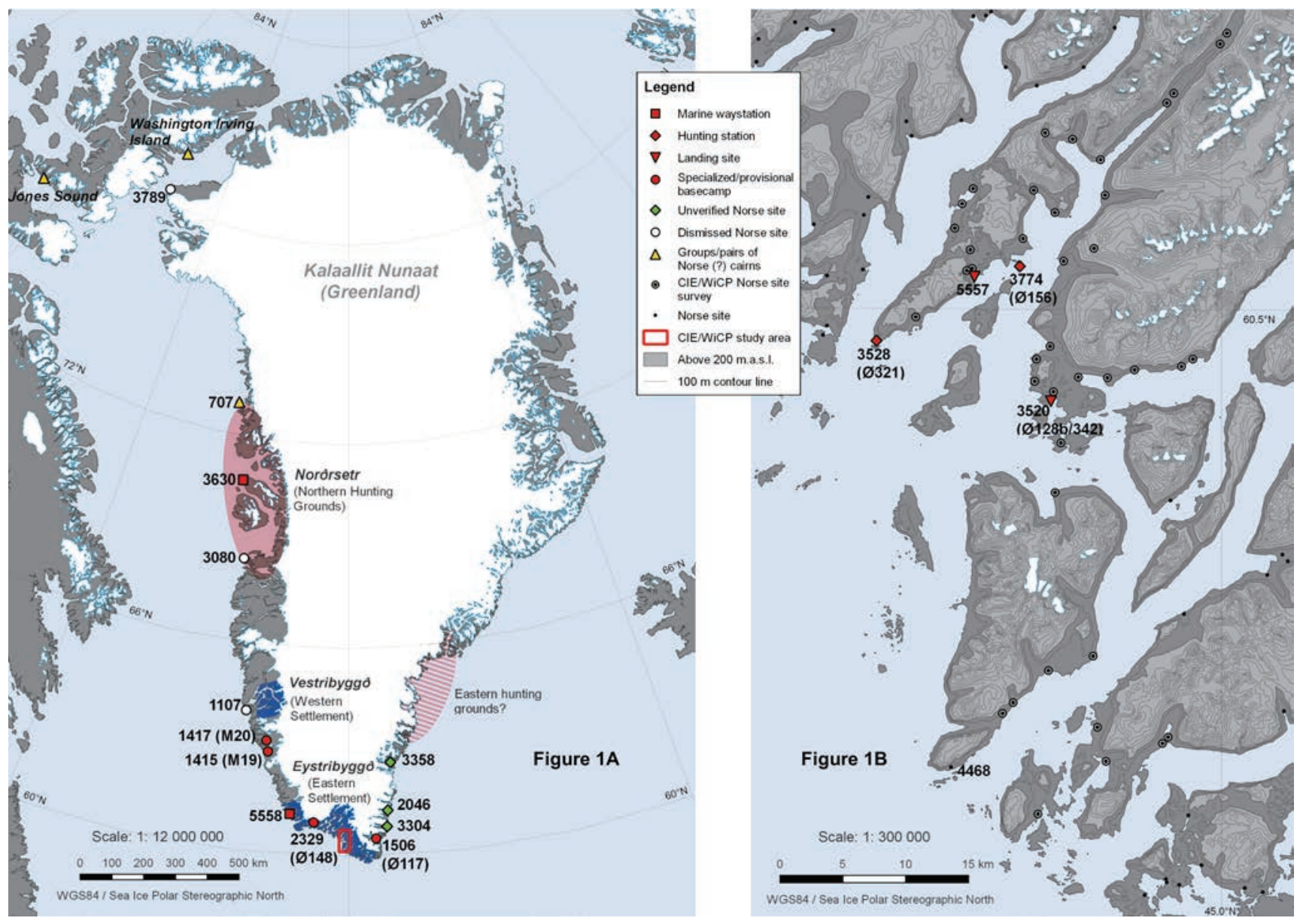

Figure 1. Maps showing Greenland (1A) and the Comparative Island Ecodynamics (CIE)/Winter is Coming Project (WiCP) study area (1B) with indications of Norse settlement and hunting areas, as well as Norse sites and marineshieling types discussed in the text (map by the author).

time (e.g., Dugmore et al. 2009; McGovern 1985a; Ogilvie et al. 2009; Perdikaris and McGovern 2008; Smiarowski et al. 2017). Marine mammals, especially seal, greatly dominate the wild species. Isotopic analysis of Norse skeletons displays similar patterns with some late period individuals subsisting on up to $80 \%$ marine protein (Arneborg et al. 2008; Arneborg et al. 2012a). Marine mammals were also the backbone of the Norse trade economy: high-value, low-bulk walrus ivory and skin robes, narwhal tusks, and polar bear and seal furs were the main exports valuable enough to attract foreign merchants to Greenland's distant settlements (Dugmore et al. 2007; Roesdahl 2005; Star et al. 2018).

Predictably, Norse marine-resource use and voyages to distant hunting grounds have therefore attracted considerable scholarly attention (e.g., Arneborg 1998; Ingstad 1960; Keller 2010; Ljungqvist 2005; Magnusen 1827b; Meldgaard 1995; Nansen 1911; Perdikaris and McGovern 2008; Vebæk
1991; Wormskiold 1814). Recently, systematic harvesting of marine-mammal exports has even been proposed as a primary driver for Norse expansion to Greenland (Frei et al. 2015). However, while the existence of a few archaeological sites associated with marine-resource use has been suggested (e.g., Berglund 1973; McGovern 1979; Meldgaard 1995; Thorhallesen 1776), their placing, layouts, and various functionalities have not been systematically explored.

The present study contributes to the research of Greenland Norse marine-resource use by reviewing, categorizing, and discussing archaeological evidence of various types of specialized and temporary marine sites-marine shielings-inside and outside the Norse settlements in Greenland. The study builds on years of field observations but even more so on unanticipated spinoff results from the collaborating "Comparative Island Ecodynamics in the North Atlantic Project" (CIE, 2012-2016) and "Winter is Coming Project" (WiCP, 2016-2020) 


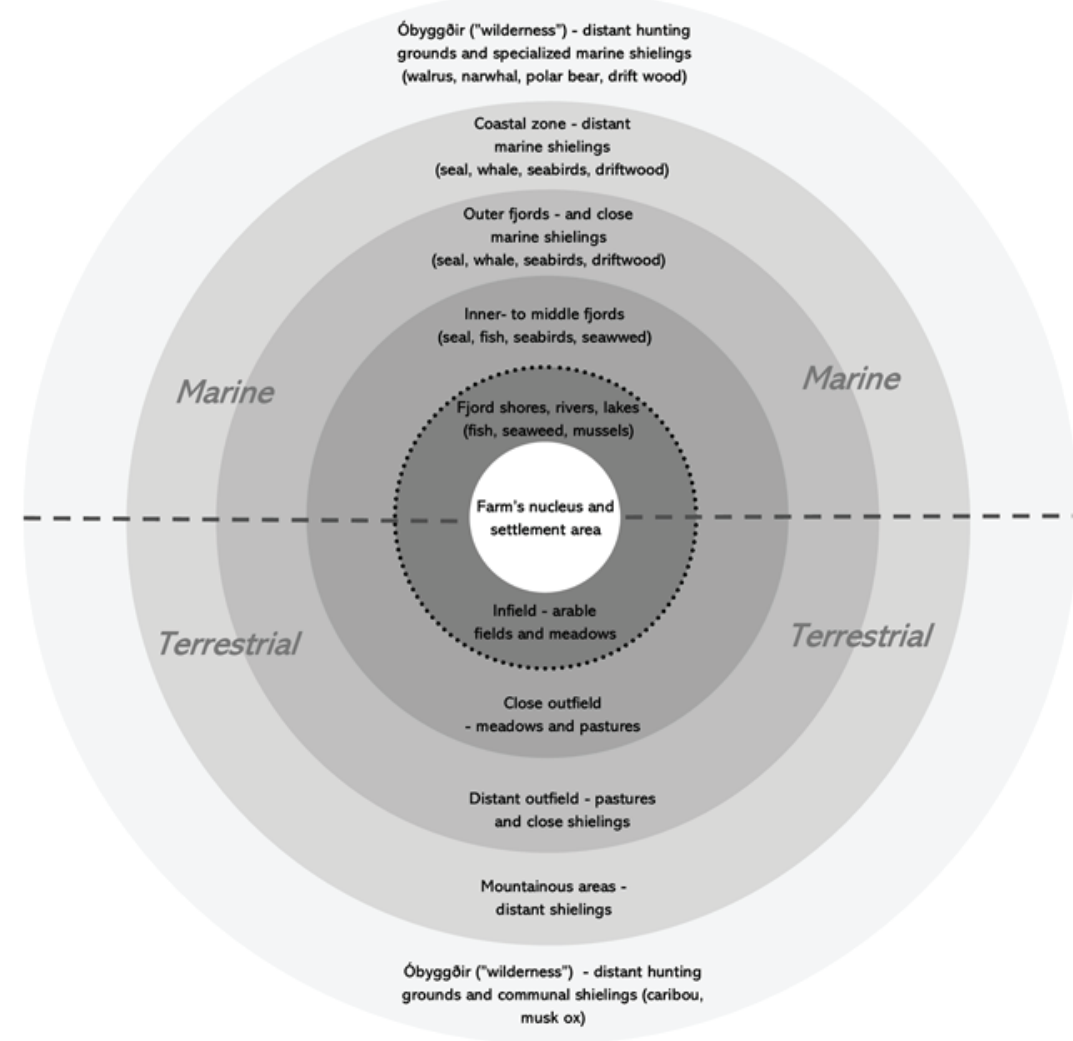

Figure 2. Conceptual Greenland Norse farm and land-/sea-resource use model (adapted from Øye 2013:Fig. 4). Besides the terrestrial resource zones suggested by Ingvild Øye, this model includes Greenland Norse marine-resource zones, the character of associated sites, and examples of the main marine resources harvested within these zones.

that study long-term human ecodynamics from the Viking Age to Early Modern North Atlantic and Greenland from superregional to site-level scales from opposite perspectives.

\section{Greenland Norse Settlement Landscapes}

The Norse Eystribyggð spanned the $\sim 400 \mathrm{~km}$ icefree area between Cape Farewell and up to $\sim 62^{\circ}$ latitude (Fig. 1). More than 560 Norse sites have, so far, been located in the Eystribyggð (Arneborg et al. 2012b), occupying the entire landscape from fjord shores to mountainous hinterlands, from the edge of the Ice Sheet to the outer fjords. However, only an estimated one to two-thirds of the sites were farmsteads (Madsen 2014b; Vésteinsson 2010), the rest being various types of satellite sites. The smaller Vestribyggð, with only 105 registered sites, was located $\sim 500 \mathrm{~km}$ to the north in the inner parts of the Nuuk- and Ameralik fjord systems (Fig. 1A) (Arneborg et al. 2012b; McGovern and Jordan 1982; Roussell 1941).
Following a North Atlantic model, farmsteads were the operational and legal centers of the notably hierarchical Norse communities in Greenland (Fig. 2). Situated in or on the edge of cultivated "infields," farmsteads were hubs for the accumulation, display, and consuming of terrestrial and marine produce, surplus, and wealth. Beyond the infield extended the "outfield." Occasionally translated as "wasteland," the outfield included resource areas of central importance to North Atlantic farms (e.g., Baug 2015; Blehr 2012; Church et al. 2016; Øye 2004, 2013). While much scholarly attention has focused on terrestrial outfield resources, Figure 2 has been adapted to local Arctic settings and conceptually suggests the matching importance of marine-resource zones in a Greenland Norse economy largely sustained by marine wildlife and resources. Whether dealing with resources in the terrestrial or marine environment, when distances from outfield resources to farmsteads became logistically impracticable, access and production were facilitated by satellite sites (i.e., shielings) (Fig. 2). 


\section{Norse Shielings: A Definition}

Previously somewhat understudied, shieling or transhumance is today recognized as an ancient, central element of pastoral farming cultures all over the North Atlantic, Scandinavia, and Europe (e.g., Carrer et al. 2016; Cheape 1996; Kupiec and Milek 2014; Mahler 2007; Reinton 1961; Skrede 2005; Sveinbjarnardóttir 1991). In Norse Greenland too, the importance of terrestrial shieling has been emphasized (e.g., Albrethsen and Keller 1986; Bruun 1895; Guldager et al. 2002; Ledger et al. 2013; Madsen 2014b; Roussell 1941).

A "shieling" in this context should be defined as a seasonal, task-specific production or logistic site. "Seasonal" because shielings were temporarily occupied, but periodically revisited, often following a yearly rhythm; "task-specific" because shielings facilitated specialized activities; "production" because shielings enabled localized produce, processing, manufacture, or storage of foodstuffs, fodder, or wares that were eventually moved to sites of accumulation, consumption, or trade (farmsteads, markets, etc.); "or logistic" because shielings could also enable long-distance movement of people, animals, foodstuffs, and goods.

This shieling definition allows for the inclusion of almost any type of seasonally occupied, specialized farming or nonfarming satellite site. Admittedly, such an open definition is somewhat at variance with the typical use of the term shieling, which is both conceptually and historicallyand whether in a North Atlantic, Scandinavian, or European context-normally associated with agropastoral transhumance (e.g., Albrethsen and Keller 1986; Reinton 1961; Svensson 2015). The reasons for upsetting this convention are several, but primarily to stress the point that the marine category of satellite sites should, at least as a starting point, be considered on par with their terrestrial counterparts: whether terrestrial or marine, shielings were a subset to "mother farmsteads" and had to draw on the same labor force and fit within their scheduling of seasonal activities-a schedule not necessarily strictly determined by the seasonality of the farming cycle, especially not in Norse Greenland where marine resources of key importance were mostly present or accessible during short seasonal windows. Also, earlier studies have demonstrated that in Greenland, even shielings associated with agropastoral activities could have a different spatial organization than elsewhere in the North Atlantic.

An open definition allows for local adaptation, changing, or multifunctionality of shielings, while at the same time avoiding to draw direct parallels with the historical or ethnographic phenomenon (Svensson 2015). In fact, earlier studies have demonstrated that in Greenland, even shielings associated with agropastoral activities could have different spatial organization than the widespread practice of lowland to highland/inland transhumance and instead reflected a horizontal movement of people and animal husbandry to pastures spread out along the fjord coasts (i.e., horizontal transhumance) (Madsen 2014a,b). Also, the only historical example of an Old Norse -setr or -setur place name-the likely origins of English word "shieling"(Foster 2018)-from medieval Greenland refers to an area in the high Arctic (see Fig. 1A) far beyond the Norse settlements and any potential agropastoral activity. A few other examples of nonagropastoral -setur place names also exist from elsewhere in the North Atlantic (Foster 2018). Shielings, whether terrestrial or marine, were undoubtedly legally organized and managed within the same socioeconomic framework of kin-based ownership, shareholding, or tenure and thereby equal parts of what comprised the entirety of North Atlantic medieval farms (Fig. 2) (Madsen 2014b; Vésteinsson et al. 2002; Øye 2005)-farms that were everywhere heavily dependent on extensive resources in the outfield or, in Greenland, beyond.

\section{Greenland's Óbyggðir}

The Eystribyggð and Vestribyggð occupied small, environmentally constrained subarctic landscape niches that allowed pastoral farming. Beyond lay thousands of kilometers of low to high arctic coastal areas, where most of Greenland's marine wildlife is located (Fig. 1A and 2) (Born and Böcher 2001). Most of the marine species and resources that provided the Norse with key household provisions-common/harbor seal, harp seal, hooded seal, seabirds, and driftwood (e.g., Enghoff 2003; McGovern 1985a; McGovern et al. 1996; Møhl 1982)—could be found in the coastal outfield near the settlements (Fig. 2). In contrast, cash-crop marine species could only be hunted in the óbyggðir (ON pl. "unsettlements") (Grove 2009), a term used by medieval authors to designate the remote coastal "wilderness" far north and east of the settlements (Fig. 1A and 2). Whether or not a medieval landscape category, perhaps even with legal implications, óbyggðir here signifies the entirety of Norse resource areas and hunting grounds beyond the settlements.

\section{Marine Hunting in the Medieval Written Record}

Medieval written sources on the Greenland Norse are few and fragmentary (e.g., Grove 2009; Halldórsson 1978; Ogilvie 1991) and descriptions 
of Norse marine hunting even scarcer. The mid13th-century Norwegian text Konungs skuggsjá (King's Mirror) provides one principal list of Norse marine exports of walrus tusks, walrus robes, and sealskins (Larson 1917). These exports are repeated in a papal letter of AD 1282 (Anderson 1906) and indirectly by medieval tax lists from the royal trade port of Bergen (Helle 1982). Only two texts contain any additional information on Norse hunting activities in Greenland's óbyggðir: Björn Jónsson of Skarðsá’s Grænlandsannáll (Greenland Annals) concerning hunting activities in the Norðrsetr (Northern Hunting Grounds) and Ívarr Bárðarson's A Description of Greenland on hunting in East Greenland. Unsurprisingly, these texts have been repeatedly mined for evidence (e.g., Gad 1965; Graah 1832; Ingstad 1960; Keller 2010; Ljungqvist 2005; McGovern 1985b; Nansen 1911; Seaver 1996; Wormskiold 1814) and are here revisited only to contextualize the archaeological evidence.

\section{Björn Jónsson's Greenland Annals: Norðrsetr}

The so-called Greenland Annals are thought to have been compiled by Jón lærði Guðmundsson (1574-1658) in 1623, but the passages on Norðrsetr survive in a revised copy by Björn Jónsson of Skarðsá (1574-1655) from ca. 1643 (Halldórsson 1978). Geographically, Norðrsetr has long since been identified as the Disko Bay and Upernavik region (e.g., Arneborg 1998; Wormskiold 1814). The three passages on the Norðrsetr hunt in the Greenland Annals likely reflect a combination of knowledge from earlier medieval sources and contemporary Icelandic lore on Norse Greenland (Grove 2009; Halldórsson 1978; Jones 1986; Jónsson 1899; Seaver 1996):

One passage states that:

The Greenlanders regularly need to undertake northbound sea voyages to the uninhabited parts [óbyggðum] of the land's northern end, or peninsula, both for lumber, hunting and fishing [aflabragða]: it is called Greipum and Króksfjarðarheiði. It is a very long sea voyage (translated by Orri Vésteinsson after Halldórsson 1978:49-50). ${ }^{1}$

Under the heading of "About the People of the Northern Hunting Grounds [Norðursetufólk] in Greenland" (translated by Orri Vésteinsson after Halldórsson 1978:55), a second passage provides additional information:

\footnotetext{
All the wealthy farmers [stórbændur] in Greenland had large ships and vessels built to send to the Northern Hunting Grounds [Norðursetu] to procure all kinds of hunting [afla] and hewed timbers [telgdum viðum] . . . They went there mostly for seal fat because the seal hunting was altogether
}

better there than at home in the settlements. Melted seal fat was poured into skin containers [húðkeipa] and hung up to be cured by the wind in drying sheds [útihjöllum]. . . . The Norðursetumenn had their camps [búðir], or huts [skála], both in Greipum and some in Króksfjarðarheiði (Halldórsson 1978:55).

A final, third passage in the "Greenland Annals" simply states that "Norðurseta"-a verbal form-could also signify the period of hunting in Greipum and Króksfjarðarheiði (Halldórsson 1978:50).

\section{Ívarr Bárðarson's Description of Greenland: East Greenland}

Ívarr Bárðarson’s Description of Greenland from the later 14th century is generally considered a less problematic text (Halldórsson 1978; Jónsson 1930; Mathers 2009) but only concerns hunting activities in East Greenland. The account begins far east of Eystribyggð in the uninhabited Bærefiord, of which is stated:

There run also countless whales in the fjord, and there is never a lack of fish there; and in the fjord there are whalers, hunting by common whaling rights but with the bishop's permission; this fjord belongs to the cathedral (Mathers 2009:71).

A couple of fjords overlay "a harbor called Fimbuder (Finsbúðir)" and even further up the coast was "a large island, called Kaarsøø. Here there are usually hunters looking for polar bears; they must have the bishop's permission as the game belongs to the cathedral" (Mathers 2009:71).

First, it should be noted that Bárðarson's reference to "whales" (and "whalers") and "fish" is potentially misleading, as he could have meant walrus and seal or all of the above. Medieval inconsistency in species terminology is quite common. Second, the extent of the bishop's properties should perhaps not be overestimated: being a subordinate cleric's report to church authorities in Norway, Bárðarson's account could reflect some measure of embellishment or idealism. Neither is it clear exactly what was meant with the term "belong" (i.e., land ownership, use, or tax rights?) (Keller 1990). In any case, the hunting grounds in East Greenland were valuable enough to lay claim to, whether by intent or in praxis.

Finally, considering the considerable detail of Bárðarson's fjord and church property listing, it is surprising that the Norðrsetr is not mentioned. In fact, it is even stated that no one who valued their life would sail far north of Vestribyggð" (Mathers 2009 translation after Bárðarson 135-137). Could this indicate that the Norse in the Eystribyggð had abandoned hunting in Norðrsetr at this time and only hunted on the geographically closer east 
coast? The date of Bárðarson's description at least corresponds with the increase of Thule culture presence in the Melville Bay and Disko Bay areas (Gulløv 2016).

\section{Summary Discussion of the Medieval Written Record}

Disregarding details of uncertain meaning and geographic location, distilling these medieval accounts add several perspectives to the character of Norse marine hunting in the óbyggðir:

1. Marine hunting in both Norðrsetr and on the east coast appears to have been frequent, probably an annual activity (McGovern 1985a). This recurrence is implied by the place name Norðrsetr itself, which translates directly as the "northern places (of temporary occupation)" or even the "northern shieling" (Bugge 1914; Ingstad 1960; Nansen 1911).

2. Marine hunting seems to have been undertaken by specialist hunters and crews (i.e., "Norðursetufólk," "Norðursetumenn," "whalers," and "polar bear hunters"). At least, this would theoretically appear a plausible arrangement as the expediency and safety of arctic marine hunting required highly developed skills and local environmental knowledge.

3. Marine-hunting expeditions and crews were apparently organized or sponsored by wealthy farmers (i.e., stórbændur) owning ships with regional range and some cargo capacity (i.e., large ships and vessels). Again, this appears a quite plausible setup considering the distances to marine-hunting grounds. In West Greenland, large walrus populations are found north of $65^{\circ}$ latitude with main summer haul-outs in the Disko Bay area (Born et al. 1994), whereas narwhal summering grounds are located in Melville Bay and Inglefield Bredning (Heide-Jørgensen et al. 2010) (i.e., 1,600-1,800 km north of Eystribyggð and 500-1,300 km of Vestribyggð) (Fig. 1A). In East Greenland, walrus and narwhale summering grounds are historically found mainly in the large fjords above $64^{\circ}$ latitude, around $480 \mathrm{~km}$ north of Cape Farewell (Dietz et al. 1994; Heide-Jørgensen et al. 2010; Witting and Born 2005).

4. Marine hunting in the óbyggðir appears to have been motivated not only by marine cash crops but could also have provided a steady supply of animal protein and oil from walrus, whale, seal, and polar bear, as well as driftwood and seal tar. This scenario seems repeated in the King's Mirror, which states that apart from domestic animals, the Norse
Greenlanders subsisted on "the flesh of various kinds of game, such as reindeer, whales, seals, and bears" (Larson 1917:145). However, as there is little driftwood above $66^{\circ}$ latitude on Greenland's west coast (Gulløv 2016), the Greenland Annals' reference to it as an important Norðrsetr resource is clearly misinformed. However, driftwood is plentiful below $66^{\circ}$ latitude, as well as on the east coast, and could have been collected and used for ballast while traveling to and from the hunting grounds.

5. Specific laws and use rights appear to have applied to marine-hunting grounds in the óbyggðir ("common whaling rights" by the "bishop's permission"). A concern with legal conditions in the óbyggðir is notable in a passage in Hákonar saga Hákonarsonar from the 1260s, where it was decreed that the King of Norway was to be compensated for all murders, on both Norwegians and Greenlanders, and whether committed in the settlements or Norðrsetr (Bugge 1914).

6. Marine hunting was logistically supported by features in the óbyggðir that facilitated both temporary habitation (i.e., booths or houses in Greipum and Króksfjarðarheiði, Finsbúðir in East Greenland) and specialized buildings (i.e., drying sheds)—essentially, various types of marine shielings. Other written sources mention a Karlsbúðir, located in the north (Jónsson 1899; Wormskiold 1814), and famous Leifsbúðir in Vínland, possibly the site of L'Anse aux Meadows, Newfoundland (Fig. 25).

\section{An Interpretational Framework for Greenland Norse Architecture}

Greenland's cultural landscapes are remarkable in that they preserve near complete, fossilized Norse settlement landscapes representing some 450 years of occupation. The good state of preservation extends to many singular Norse features, or ruins, making it possible to surface-record accurate dimensions and architectural details. This visibility is a rarely auspicious archaeological situation in a North Atlantic, where sites have often been in continuous use at least since the Viking Age (e.g., Arge et al. 2005; Bolender et al. 2011; Bruun 1928b; Vésteinsson et al. 2002).

However, while many archaeological site surveys have reported ruin dimensions and architectural details (e.g., Albrethsen and Arneborg 2004; Guldager et al. 2002; Krogh et al. 1980), few studies have used the observations systematically (see, however, Bruun 1895; Krogh 1982; Roussell 1941). Building on methodology developed 
during the Vatnahverfi Project 2005-2014 (Madsen 2014b), and refined during the WiCP/CIE field campaigns from 2013-present, this section outlines a developing interpretational framework for surface identification of Norse ruin and site functionalities based on systematic observation of following parameters: building dimensions, materials, and orientation; micro-topographical setting, as well as local to regional location and resource access. Because several of these parameters are self-explanatory or described for the individual sites, only those of unfamiliar or particular meaning, and listed in tables 1-3, are explained in the following subsections.

\section{Norse Building Materials}

The building materials used by the Norse Greenlanders were turf, stone, and wood. The first two materials could be procured locally, whereas large buildings timbers had to be retrieved from the coastal outfield, locally or regionally, in the form of driftwood (Fig. 2). Each building material had certain properties, and shortcomings, and careful selection and combination materials determined the buildings' functional capacities.

Table 1 presents a functional classification scheme for Norse building-material types as observable during surface surveys. The scheme draws partly on field observations, partly on a great range of North Atlantic architectural studies: from studies on Norse building customs in Greenland (e.g., Albrethsen 1982; Albrethsen and Ólafsson 1998; Arneborg 2004; Bruun 1895; Bruun 1928b; Krogh 1982; Roussell 1936; Roussell 1941; Vebæk 1943), North Atlantic archaeological or ethnographic parallels (e.g., Berson 2002; Bruun 1897; Bruun 1928a; Gestsson 1986; Griffiths and Harrison 2011; Jim 2017; Matras 2005; Skre 1996; Small 1967; Stummann Hansen 2013; Thorsteinsson 1982), and reconstructive or experimental archaeology (e.g., Guðmundsson and Ágústsson 2006; van Hoof and van Dijken 2008). Admittedly, some observations in the interpretation scheme (Table 1) are inferential and highly qualitative. However, this is of limited concern since its purpose is not such much to provide definite categories, as it is to make explicit the interpretive process.

Summarizing the information in Table 1, turf walls had insulating properties-the thicker, the more insulating - were wind, water, and moisture impermeable, and therefore turf was the principal material in habitation buildings for human and animals. However, especially in arctic Greenland, where grassland is scarce and vegetation recovery extremely slow (Forbes 2015), turf was not an inexhaustible resource. As a result, the unworked stone was used extensively as a protective and stabilizing element in turf buildings, as well as in pure stone architecture, when buildings were required to be ventilated, cool, dry, and stable. Wooden buildings also appear to have existed (Krogh 1976, 1982; Madsen 2014b) but are not considered further here.

\section{Microtopographical Setting}

The functional advantages and shortcomings of various Norse building materials were enhanced or diminished through the careful and intentional use of, and adjustment to, key microtopographical features: structure building ground; building/site wind and sunlight exposure or shelter/shade; and boat-landing conditions.

\section{Building Ground}

Not to be confused with "building foundation," "building ground" refers to the natural surface on which a building was raised. To keep structure interiors dry, the Norse always situated their buildings on drained ground. However, two basic functional properties of these drained surfaces should be observed: a) soil had heat retaining, or at least minimally heat-draining, properties and was the preferred building ground for insulated (cold-period) habitation buildings; whereas b) bedrock/cliff enabled easy water runoff but also caused major heat drain. It was, therefore, unsuited for cold-period habitation and instead preferred in buildings that had no heat requirements or needed to be kept cool (e.g., food and equipment stores).

\section{Building/Site Wind and Sunlight Exposure or Shelter/Shade}

A critical microtopographic feature intentionally selected for was wind and sun exposure or shelter/ shade: a) in buildings or sites serving human or livestock habitation, insulating or heat retaining properties were enhanced by selecting for sheltered and sunny locations; whereas, b) buildings or sites that needed to be kept cool and/or ventilated were situated to ensure maximum wind exposure and/or shade (Madsen 2014b).

This classification scheme applies a four-category classification of wind exposure/-shelter where a building/site is considered (tables 2 and 3): a) "fully exposed" if open to winds from all directions; b) "exposed" if open to prevalent winds from two or three cardinal directions and situated to increase wind exposure (e.g., built at high elevation when lower locations were optional); c) "partly sheltered" if protected from prevalent winds from two cardinal directions and situated to reduce wind exposure (e.g., placed under a cliff or hill); d) "very sheltered" if protected from winds 
Table 1. Summarized classification scheme for the functional interpretation of archaeological surface remains of Greenland Norse architecture, which is applied to the individual ruins of marine shielings in present study. In addition to describing the type and original built of building walls, the table outlines the surface appearance of ruins and basic functional characteristics of each wall and building-material types.

\begin{tabular}{lll}
\hline Wall type and build & $\begin{array}{l}\text { Wall/building material } \\
\text { type description }\end{array}$ & $\begin{array}{l}\text { Ruin surface appearance } \\
\text { in the field }\end{array}$ \\
\hline $\begin{array}{l}\text { Type 1: Turf wall } \\
\text { (and roofing) }\end{array}$ & $\begin{array}{l}\text { Wall built of turf blocks, } \\
\text { directly on the ground } \\
\text { or, more commonly, on } \\
\text { a single- or double row } \\
\text { stone foundation of one or }\end{array}$ & $\begin{array}{l}\text { Well preserved: grassy } \\
\text { banks tracing the original } \\
\text { feature wall lines; or, }\end{array}$ \\
$\begin{array}{ll}\text { a couple of courses, often } \\
\text { with some soil/rubble/ }\end{array}$ & $\begin{array}{l}\text { disintegrated, as a distinct } \\
\text { stone foundation of one } \\
\text { or a couple of courses, } \\
\text { and filling. Wall width(s) } \\
\text { normally }>0.80 \mathrm{~m} .\end{array}$ & $\begin{array}{l}\text { collapse stone. } \\
\end{array}$ \\
& & $\begin{array}{l}\text { Collapsed: grassy, uneven } \\
\text { (farm) mounds or low }\end{array}$ \\
& & hummocks. No or very \\
& & few visible collapse stone.
\end{tabular}

\section{Type 2: Turf/stone} wall

Type 3: Dry-stone walls

3a. Freestanding single-skin drystone wall
Wall built in relatively regular, alternating layers of turf blocks and stones, raised on (rarely) singleor (often) double row stone foundation of one or a couple of courses. Wall width(s) normally $\sim 0.6-1.0 \mathrm{~m}$.

Well preserved: easily traceable walls of stones set in turf and often preserved in several courses.

Collapsed: indistinct stone wall lines, sporadically standing a few courses high, and raised on singleor double-row stone foundations; or as grassy (farm) mounds or low hummocks many protruding stones. Considerable amounts of visible collapse stone.

Can be separated on following subtypes:

Dry-stone walls built in often somewhat irregular courses/layers, at times with thin interlaying turf mats and turf wall superstructure, either directly on the ground or on a single row stone foundation. Wall width(s) normally $0.5-8.0 \mathrm{~m}$.
Well preserved: distinct stone walls, often including natural boulders or cliffs, and preserved in several, often irregular, courses.

Collapsed: indistinct, but identifiable walls of collapse stone, most sliding or tumbling down the stones, boulders or cliffs in the foundation. Some to considerable amounts of visible collapse stone.
Functional properties

Heat insulating, water, wind, and moisture impermeable. Built for cold-period (or yearround) human and animal habitation.

Turf is economical and stable, but less heat insulating and water, wind, and moisture impermeable than Type 1 walls. Built for seasonal warm-period human and year-round animal habitation.

Expediently and easily procured building materials, partly sheltering, but heat draining. Used in pens, dikes, and other freestanding enclosure walls (e.g., pens, rock shelters, etc.). 
Table 1. (Continued)

\begin{tabular}{|c|c|c|c|}
\hline Wall type and build & $\begin{array}{l}\text { Wall/building material } \\
\text { type description }\end{array}$ & $\begin{array}{l}\text { Ruin surface appearance } \\
\text { in the field }\end{array}$ & Functional properties \\
\hline $\begin{array}{l}\text { 3b. Dry-stone } \\
\text { wall facing }\end{array}$ & $\begin{array}{l}\text { Dry-stone wall built in } \\
\text { mostly regular courses/ } \\
\text { layers with no adhesive } \\
\text { or, alternatively, with } \\
\text { thin interlaying turf mats, } \\
\text { against and to support/ } \\
\text { protect the interior or/ } \\
\text { and exterior of a turf } \\
\text { wall (Type } 1 \text { or } 2 \text { ). } \\
\text { Wall width(s) normally } \\
\sim 0.4-6.0 \mathrm{~m} \text {. }\end{array}$ & $\begin{array}{l}\text { Well preserved: distinct } \\
\text { stone walls in several } \\
\text { regular courses lining a } \\
\text { Type } 1 \text { or } 2 \text { turf wall. } \\
\text { Collapsed: more or less } \\
\text { indistinct stone wall } \\
\text { lines leaning against } \\
\text { turfy banks, sporadically } \\
\text { standing a few courses } \\
\text { high, and inward/outward } \\
\text { sliding collapse stone. } \\
\text { Considerable visible } \\
\text { collapse stone, most on } \\
\text { one side of turf bank. }\end{array}$ & $\begin{array}{l}\text { Expediently and easily } \\
\text { procured building } \\
\text { materials, wind- and } \\
\text { water protective and } \\
\text { durable. Built for } \\
\text { protection of insulating } \\
\text { turf walls (i.e., increased } \\
\text { stability and durability } \\
\text { of human and animal } \\
\text { habitation buildings). }\end{array}$ \\
\hline $\begin{array}{l}\text { 3c. Roof- } \\
\text { supporting } \\
\text { dry-stone } \\
\text { double-skin wall } \\
\text { (double dike) }\end{array}$ & $\begin{array}{l}\text { Dry-stone double-skin } \\
\text { wall built mostly in } \\
\text { regular courses/layers } \\
\text { with no adhesive, and at } \\
\text { least one of the following } \\
\text { traits: i) alternating } \\
\text { thicker and thinner } \\
\text { courses; ii) larger stones } \\
\text { in the lower courses; } \\
\text { iii) heavy foundation and, } \\
\text { especially, corner stones; } \\
\text { iv) stone wedges/pinning } \\
\text { to level uneven stones in } \\
\text { the courses; v) hearting } \\
\text { with small to medium } \\
\text { sized stones Wall width(s) } \\
\text { normally } ~ 0.8-1.0 \mathrm{~m} .\end{array}$ & $\begin{array}{l}\text { Well preserved: distinct } \\
\text { double-skin walls } \\
\text { standing almost intact } \\
\text { (see description) with } \\
\text { few surrounding collapse } \\
\text { stone. } \\
\text { Collapsed: faintly } \\
\text { observable double-row } \\
\text { wall foundations or } \\
\text { lines standing up to a } \\
\text { few stone courses high } \\
\text { and surrounded by great } \\
\text { amounts of collapse stone. }\end{array}$ & $\begin{array}{l}\text { Expediently and easily } \\
\text { procured building } \\
\text { materials, ventilated } \\
\text { and cool, highly stable } \\
\text { and durable. Built for } \\
\text { airdrying and storage. } \\
\text { Occasionally used in } \\
\text { freestanding boundaries } \\
\text { or enclosure walls. }\end{array}$ \\
\hline $\begin{array}{l}\text { 3d. Roof- } \\
\text { supporting } \\
\text { drystone double- } \\
\text { skin wall with } \\
\text { (double dike) fill } \\
\text { or hearting }\end{array}$ & $\begin{array}{l}\text { Dry-stone walls with all } \\
\text { the elements of Type 3c, } \\
\text { but with fill/hearting of } \\
\text { the double-skin wall with } \\
\text { small stones and rubble, } \\
\text { occasionally some turf } \\
\text { lumps, soil or gravel. } \\
\text { Wall width(s) normally } \\
\sim 0.8-1.2 \mathrm{~m} \text {. }\end{array}$ & $\begin{array}{l}\text { Well preserved: distinct } \\
\text { double-skin walls } \\
\text { standing almost intact } \\
\text { (see description). } \\
\text { Collapsed: faintly } \\
\text { observable double-row } \\
\text { wall foundations or } \\
\text { lines standing up to a } \\
\text { few stone courses high } \\
\text { and surrounded by great } \\
\text { amounts of collapse stone. }\end{array}$ & $\begin{array}{l}\text { Expediently and easily } \\
\text { procured building } \\
\text { materials, somewhat } \\
\text { ventilated and water } \\
\text { impermeable, cool, highly } \\
\text { stable and durable. Built } \\
\text { for storage. }\end{array}$ \\
\hline
\end{tabular}


Table 1. (Continued)

\begin{tabular}{|c|c|c|c|}
\hline Wall type and build & $\begin{array}{l}\text { Wall/building material } \\
\text { type description }\end{array}$ & $\begin{array}{l}\text { Ruin surface appearance } \\
\text { in the field }\end{array}$ & Functional properties \\
\hline $\begin{array}{l}\text { 3e. Protective } \\
\text { dry-stone (and } \\
\text { turf) wall with } \\
\text { fill or hearting }\end{array}$ & $\begin{array}{l}\text { Similar to Type } 3 \mathrm{~d} \text { or } \\
\text { with alternating courses } \\
\text { of stone and thinner turf } \\
\text { mats. Occasionally built } \\
\text { to the height of the inner, } \\
\text { roof-supporting wall, } \\
\text { but more often with a } \\
\text { superstructure of pure } \\
\text { turf wall (Type 1). }\end{array}$ & $\begin{array}{l}\text { Same as Type } 3 \mathrm{~d} \text {, but } \\
\text { with considerably less } \\
\text { collapse stone, often } \\
\text { spilling outwards from } \\
\text { the building. }\end{array}$ & $\begin{array}{l}\text { Built as a weather } \\
\text { protective, water- and } \\
\text { wind-impermeable casing } \\
\text { of/shell for a wooden } \\
\text { inner structure/building. }\end{array}$ \\
\hline 4: Wooden wall & $\begin{array}{l}\text { Wooden wall raised on } \\
\text { single row dry-stone } \\
\text { foundation/sill. Wall } \\
\text { width(s) normally } \\
0.3-0.5 \mathrm{~m} \text {. }\end{array}$ & $\begin{array}{l}\text { Visible as single row dry- } \\
\text { stone foundations with } \\
\text { no surrounding collapse } \\
\text { stones. }\end{array}$ & $\begin{array}{l}\text { Ventilated. Built for } \\
\text { airdrying and storage. }\end{array}$ \\
\hline
\end{tabular}

from three or four cardinal directions and built at low elevation. Sunlight exposure is classified by noting directional angles of received, unobstructed sunlight. Both parameters are preferably observed in the field, but can —at least on site level—be reconstructed from high to medium precision elevation models, in the present study using the Polar Geospatial Center's ArcticDEM 2-m digital elevation model (Porter et al. 2018; www.pgc.umn. edu/data/arcticdem/).

\section{Boat-Landing Conditions}

"Boat-landing conditions" summarizes a qualitative assessment of the ease of approaching and anchoring or beaching a boat at a site. Boat-landing conditions are described as a) "good" when a natural harbor offers easy an approach and sheltered anchoring or beaching conditions; b) "average" when a landing site is usable but unsuited for anchoring or beaching under certain wind or wave conditions; and, c) "poor" when approaching, anchoring, or beaching at a site is difficult or impracticable. The assessment assumes that the boat is small, flat bottomed, and light enough for a small crew to carry or drag onto land. At visited sites, this assessment is experienced based; otherwise, it is based on prior descriptions.

\section{Norse Marine Shielings in Greenland}

This section presents 17 sites in Greenland that have-directly or inferentially-been suggested or confirmed as related to Norse marine-shieling activities. Five sites are located within the CIE/ WiCP study area (Fig. 1B), while the remainder are examples of Norse sites either occupying environmental and geographic settings that preclude pastoral farming (above $66^{\circ}$ latitude and on Greenland's eastern coast) or are in the far periphery of the main settlement areas (i.e., Greenland's óbyggðir) (Fig. 1A).

The sample only includes sites that been revisited by archaeologists or experienced observers and where documentation exists in published literature or the archives of the Danish and Greenland National Museums. Sites are numbered with the current Nunatta Katersugaasivia Allagaateqarfialu (Greenland National Museum and Archives) heritage number (NKAH no.), as well as the old numbering system $(\varnothing, \mathrm{V}$, or $\mathrm{M}$ numbers for the eastern, western, and middle settlements, respectively) applicable to Norse sites registered before 1982. Descriptions of site setting and resource access are based on either observation, prior descriptions, or simply on environmental setting (i.e., coastal versus inner fjord). Due to great local variability and lacking evidence, site descriptions do not systematically consider relative sea-level rise. However, it is noted that relative sea-level change over the last 1,000 years is estimated to range between 0.5 and $4 \mathrm{~m}$ in southwestern and southern Greenland (Long et al. 2012; Mikkelsen et al. 2008).

While the discussed sample of sites is evidently not complete, it does represent the most-likely examples of sites with nonfarming functionality (i.e., potential marine shielings). To the author's knowledge, this is the first time such 


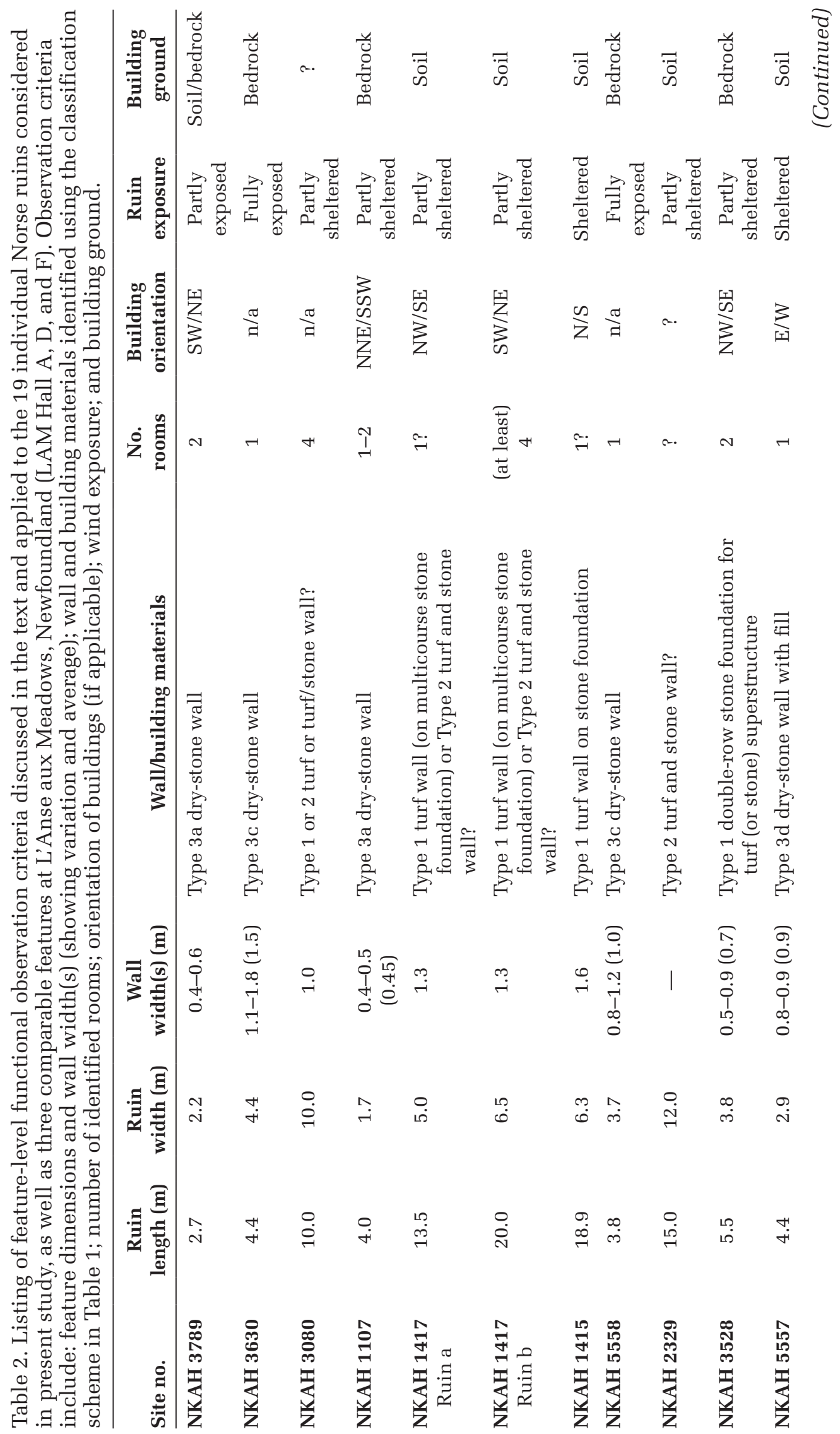




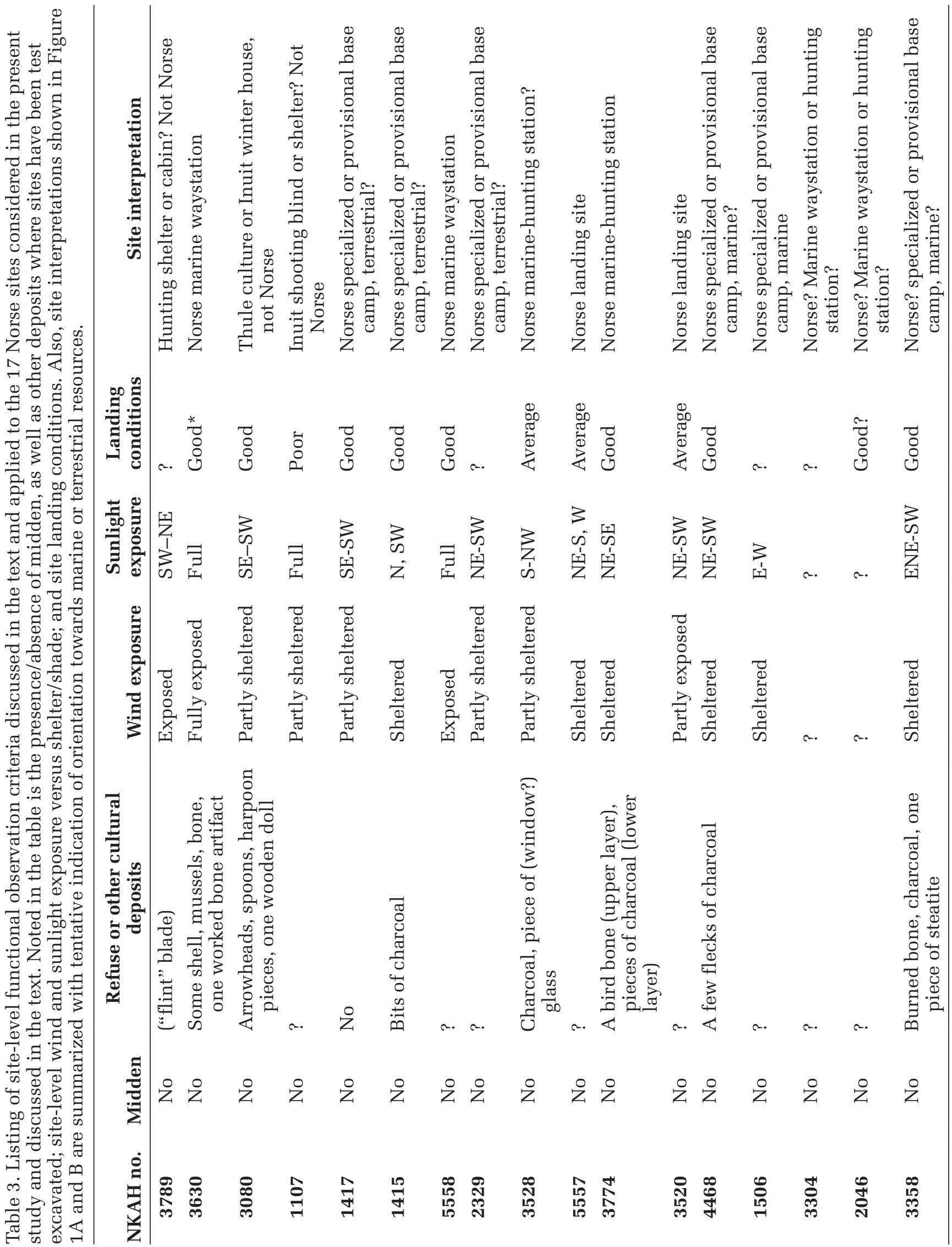




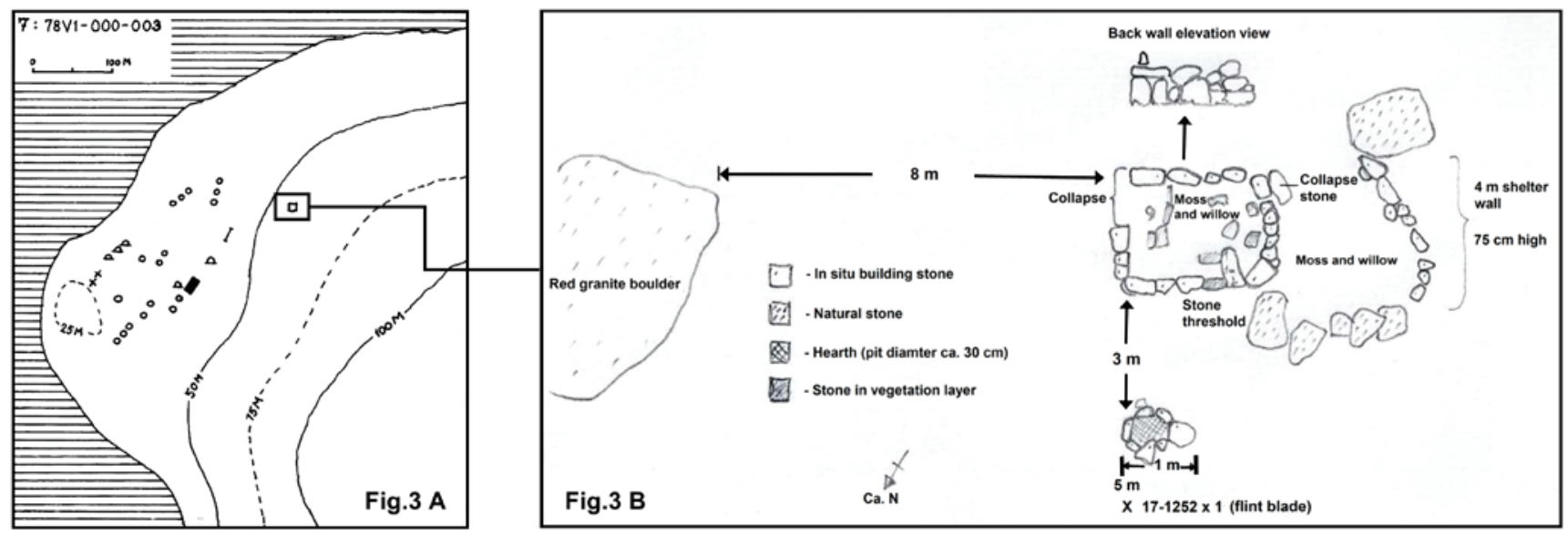

Figure 3. A. Site sketch overview plan of Late Dorset, Thule culture, and suggested Norse features (indicated) at NKAH 3789, Inglefield Land (modified after Appelt et al. 1998:Fig. 1). B. Detailed sketch plan of the suggested Norse feature at NKAH 3789 (modified after Torben Diklev 1993, with permission).

types of Norse sites areas have been presented collectively. The extent and detail of individual site documentation are of course highly variable, and not all the previously-outlined observation parameters can be described for all sites.

\section{Possible Norse Marine Shielings above $66^{\circ}$ Latitude}

\section{NKHA 3789, Inglefield Land, $78^{\circ}$ Latitude}

NKAH 3789 includes one suggested Norse ruin situated 30-60 meters above sea level (masl) and 150-160 m northeast of a raised beach with Paleo-Inuit and Thule culture features, $2 \mathrm{~km}$ east of Littleton Island, Inglefield Land (Fig. 1A and 3). Published prior site descriptions are in Appelt et al. (1998) and Gulløv (1997). Additional information for this study include descriptions by Hans Lange, Greenland National Museum and Archives, and David Qaavigaq (personal communication 2018), who both inspected the site in 1993, 1996, and 1997; a sketch site plan made in 1993 (Fig. 3B) by Torben Diklev (personal communication 2018), former head of Qaanaaq Museum; and two clear, but low, resolution, photos taken by archaeologist Hans Kapel in 1996 (personal communication 2019).

Some authors describe the feature as a small, square stone house "more Norse-like than similar structures from West Greenland" (Appelt et al. 1998:139). However, Diklev's sketch site plan (Fig. 3B), which Kapel's photos confirm to be very accurate, and field notes show a slightly more complex, two-part feature-its mostly square, eastern half with inside dimensions of 2.2-2.7 m. This estimate matches the description of Lange and Qaavigaq that the feature was certainly no larger than $3 \times 3 \mathrm{~m}$. Both photos and sketch plan (Fig. 3B) show this part of the feature to have Type 3a dry-stone walls (Table 1) approximately 40-60 cm wide and of somewhat irregular built with no stone wedges or pinning to stabilize the courses. The western half of the feature, which Diklev describes as a shelter wall (Fig. 3B), appears of similar build but in more irregular courses. The photos show hardly any collapse stone apart from what is seen in the sketch plan (Fig. 3B), suggesting that the walls never stood higher than their present $50-80 \mathrm{~cm}$. The building ground is a thin layer of soil on gravel or bedrock.

Based on the combined site documentation evidence and observation criteria (Table 2), the feature can almost certainly be dismissed as Norse. In Norse architecture, Type 3a single-skin drystone walls are only used in unroofed structures (i.e., pens, boundary walls, or shelter walls in simple rockshelters for animal husbandry, herders, or hunters). The fairly wind-exposed setting of the NKAH 3789's feature, its heat draining building ground, and low dry-stone walls seems to exclude such function, nor could it have served winter habitation without an inner insulating construction. The type of open-air hearth depicted in Diklev's site plan just north of the feature is not normal for sites of Norse origin and the discovery of a nearby "flint blade" (Fig. 3B)—more likely some local crystalline stone material-suggests that it could be an atypical Paleo-Inuit or Thule culture, if not a later historical Inuit or European feature.

\section{NKAH 707, Kingittorsuaq,} Upernaviarsuk, $73^{\circ}$ Latitude

In 1824, a small runestone was found on top $(\sim 300$ masl) of the steep-sided barren Kingittorsuaq 


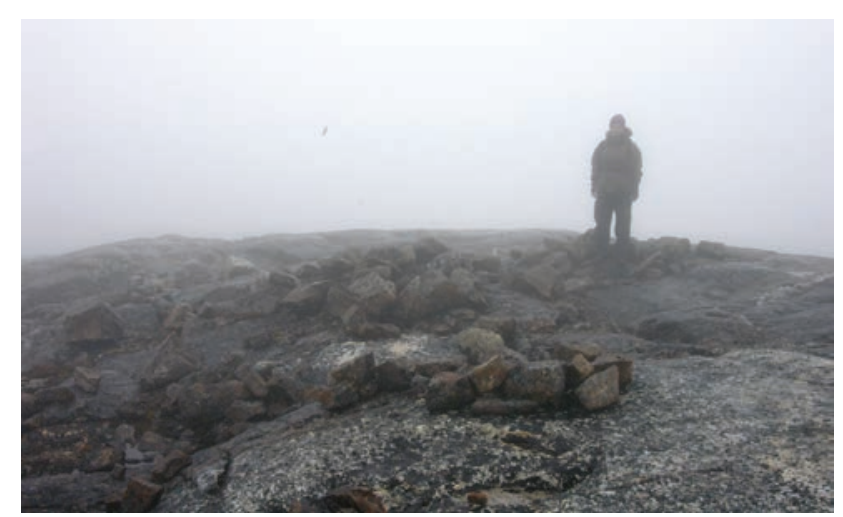

Figure 4. A recent photograph of the three collapsed cairns (NKAH 707) on top of Kingittorsuaq Island, where the famous Norse runestone was found in 1824 (photographed by Mikkel Myrup in 2009).

island, approximately $20 \mathrm{~km}$ north of Upernavik (Figs. 1A and 4) (Magnusen 1827a). The runestone has been dated to the mid-13th century and bears a concise inscription: "Erlingr Sighvatrs son carved and Bjarni porðr's son and Eindrið Oddr's son, constructed these cairns the Saturday before Rogation Day (April 24), and ..." (Ihmer 2017:243).

An 1825 inspection of the find site confirmed the existence of three cairns-all collapsed, one larger and two smaller-together forming a triangle, which was likely built while the island served as a temporary lookout for Norse on one of their summer hunting voyages (Magnusen 1827b). Published 1950 photos show the cairns in a severe state of collapse (Rosenkrantz 1967b:Fig. 3-5), but 2004 photos reveal little recent change (Fig. 4). NKAH 707 should possibly be grouped with other examples of groups or pairs of cairns raised on islands: on Washington Irving Island, Kane Basin (McCullough and Schledermann 2009; Schledermann 2000), and in Jones Sound, Ellesmere Island (Isachsen and Isachsen 1932).

Although not a marine shieling by present definition, the Kingittorsuaq runestone is central in that it presently provides the northernmost confirmed evidence of Norse activities in Greenland (i.e., perhaps even the northern extent of Norðrsetr). Importantly, the precise date of the raising of the cairns to April 24. Arneborg (2004) places Norse hunters in the region at such early time in the year that they could have overwintered in the vicinity or at least somewhere in the Norðrsetr (Nansen 1911). This timing would, as implied by the medieval written record, suggest the existence of Norse habitation sites in the northern parts of Greenland's óbyggðir.

\author{
NKHA 3630 ("The Bear Trap"), \\ Pullassuaq, Nuussuaq, $70^{\circ}$ Latitude
}

This likely Norse site includes a single ruin located on the seaward, exposed western tip of the Nuussuaq Peninsula's, northern Disko Bay (Fig. 1A, 5, and 6). While most scholars have agreed on the ruin's Norse origin, several functional interpretations have been offered: a polar bear trap (e.g., Egede 1740; Giesecke 1910; Pingel 1833; Steenstrup 1893); a provisional "cooler" for a deceased Norse hunter (Rosenkrantz 1967a); some form of house (Magnusen 1827b); a hunting cabin (Ingstad 1960); a storehouse for walrus and narwhal tusks (Ljungqvist 2005; Meldgaard 1965, 1995); or a chapel for Norse hunters in the óbyggðir (Meldgaard 1965).

The ruin is almost perfectly square with external measurements of $\sim 4.4 \times 4.4 \mathrm{~m}$, Type 3c (Table 1) dry-stone double walls $1.10-1.78 \mathrm{~m}$ wide, and preserved to a height of $\sim 1.6 \mathrm{~m}$ (Fig. 5 and 6). Considerable amounts of collapse stone are visible in an early perspective drawing (Steenstrup 1893:Fig. 1), supporting the estimate that the walls originally stood the height of a person (Meldgaard 1995). A narrow doorway leads into a room only 1.15-1.20 m wide. Unspecified "clearing" of this room in 1878 produced finds of some mussels and snails, bone of seal and caribou, and a single $13 \mathrm{~cm}$-long tapered bone with a row of holes, assumed to be of Inuit make (Steenstrup 1893). A second "clearing" inside and outside the ruin in 1953 produced no finds (Meldgaard 1995). The two latest ruin survey plans show the ruin interior to have a narrow platform, although this is described as a small natural shelf (Fig. 5) (Meldgaard 1995; Rosenkrantz 1967a).

While lacking datable material or artifacts, NKAH 3630's Norse origin can be established with confidence based on architectural details that feature all characteristics distinct of Norse Type 3c dry-stone architecture (Table 1, Fig. 5 and 6). The ruin's clear resemblance to Norse dry-stone buildings-storehouses or skemmur-in the settlements has also previously been noted (Ljungqvist 2005; Meldgaard 1995; Steenstrup 1893). The combination of mussels, shells, and bones found during the 1878 clearing of the room is suggestive of deposits left by seabirds and foxes, although the pointed Inuit object remains puzzling. Inuit reuse of the feature, perhaps as a depot or cache, could be an explanation (Thule culture winter settlement NKAH 5085 lies just to the south). Based on its architectural traits and microtopographic setting, the "Bear Trap" is here interpreted as a Norse storehouse built to keep ventilated, dry, and cool whatever was stockpiled inside (i.e., a type of marine shieling of designated marine waystations in Table 3). 


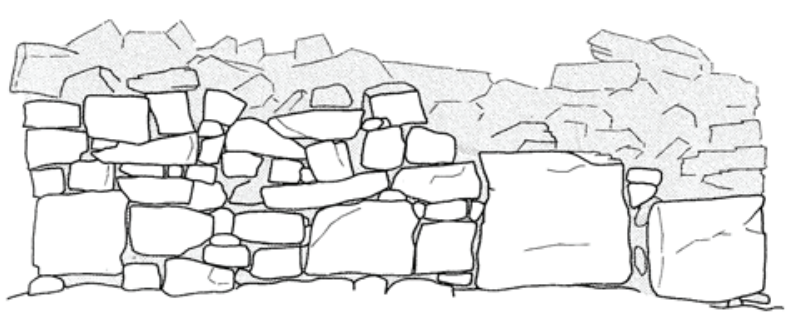

A

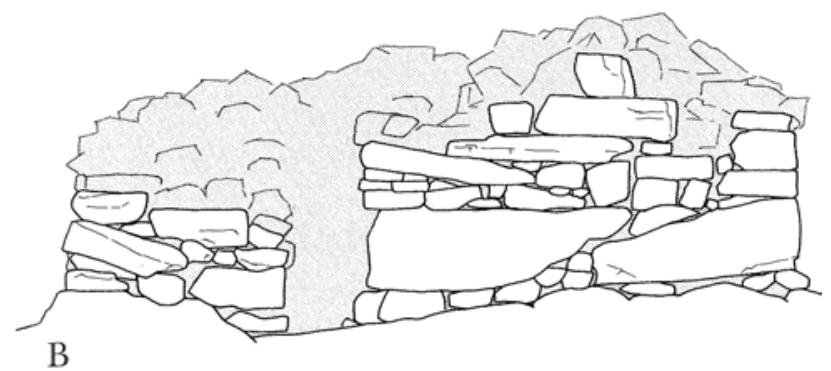

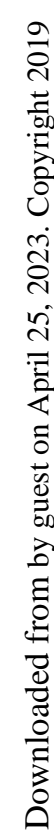

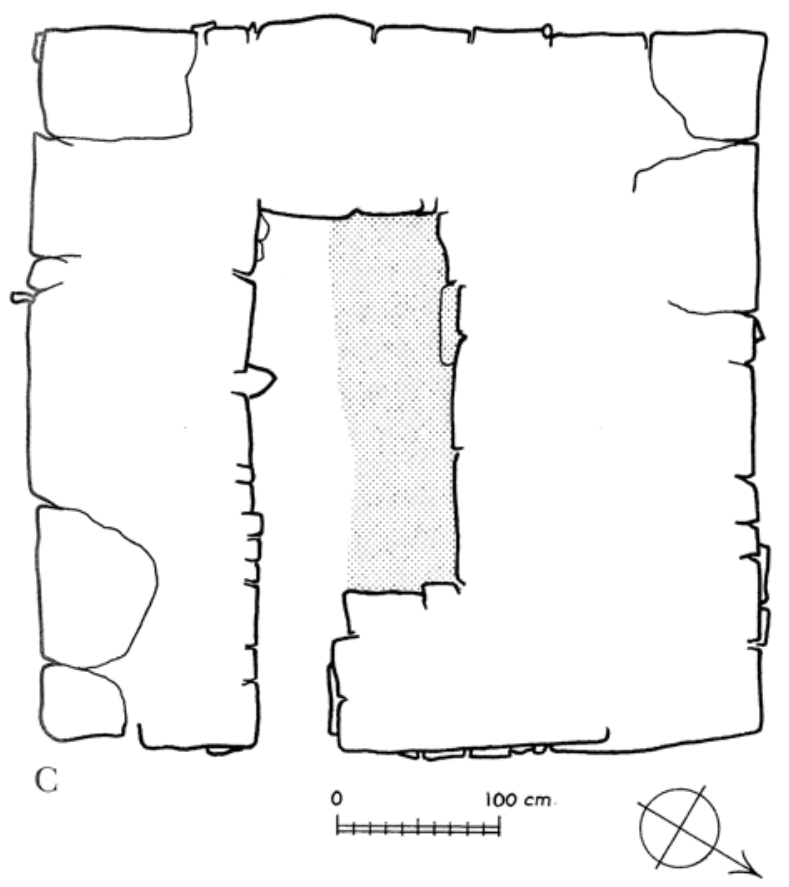

Figure 5. Detailed sketch plan of "The Bear Trap," NKAH 3630, Nuussuaq from the 1953 investigation and "clearing" of the ruin. The slightly raised natural "platform" in the northern inside half of the room is indicated (after Meldgaard 1995:Fig. e6).

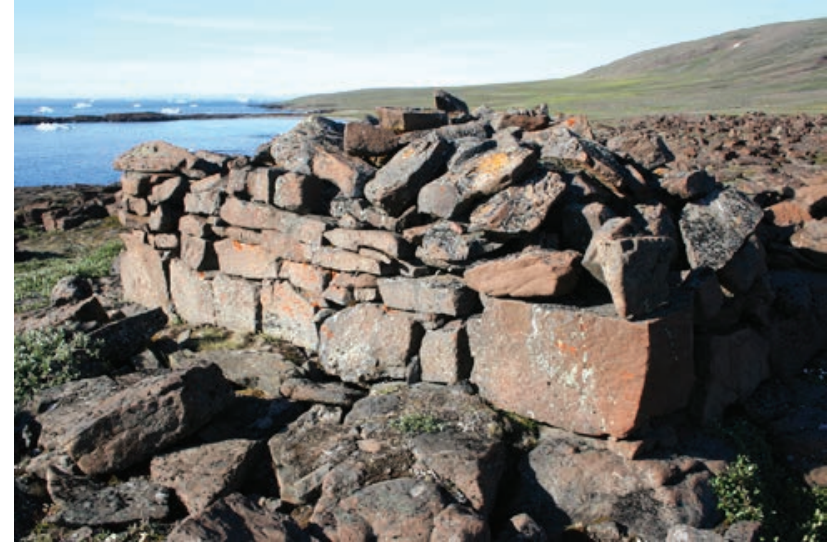

Figure 6. A recent photograph of "The Bear Trap," NKAH 3630, Nuussuaq, looking northeast along the coast. Noticeable are the massive corner foundation stones and the small "stone wedges or pinnings." Both architectural features are characteristic of Norse building customs (photographed by Bo Albrethsen, 2012).

\section{NKAH 3080, Innalik, $68^{\circ}$ Latitude}

The site includes one proposed Norse ruin located on the southwestern tip Innalik, a small island in a coastal archipelago facing the Davis Strait southwest of Disko Bay (Fig. 1A). Prior published descriptions are Bjørgmose (1967) and Petersen (1979).

The suggested Norse feature is described as having multiple rooms, external measurements of $\sim 10 \times 10 \mathrm{~m}$, and turf walls $\sim 1 \mathrm{~m}$ wide (Fig. 7). The ruin was shovel tested by Innalik local P. Sandgreen in the 1960s, who unearthed bones, a pair of bone spoons, arrowheads, fishhooks, harpoon parts, and a carved wooden figure resembling a hooded Norseman (Bjørgmose 1967; Petersen 1979).

The described artifact assembly from NKAH 3080 is clearly of later historical Inuit origin, and while the wooden doll may portray a Norseman, similar figurines have been found over a wide geographical area, mostly in Thule culture contexts (e.g., Gulløv 2008b; Sutherland 2000). Revisiting the published feature sketch plan (Fig. 7), NKAH 3080 appears to be a late Thule culture-early historical type Inuit winter house with cooking niches along a cold trap passage and not a Norse feature.

\section{Norse Marine Shielings in West and South Greenland below $6^{\circ}$ Latitude}

$$
\begin{aligned}
& \text { NKAH 1107, Mitsimmavissuaq, } \\
& \text { Nuuk Fjord, } 70^{\circ} \text { Latitude }
\end{aligned}
$$

The site includes one suggested Norse ruin located on the southern tip of Mitsimmavissuaq, an islet in 


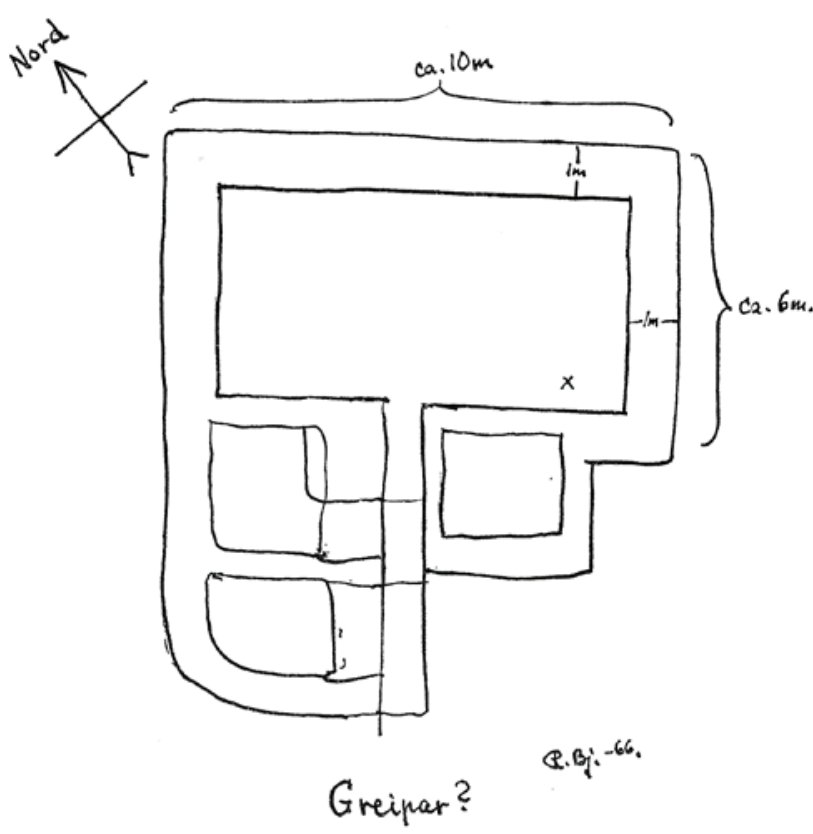

Figure 7. Rough sketch plan of the suggested Norse feature at NKAH 3080, Innalik, indicating (marked with $\mathrm{x}$ ) where a carved wooden figure resembling a Norseman was found (after Bjørgmose 1967:91). Here, the feature is interpreted as a Thule culture or later Inuit winter house, partly because of the feature's layout that includes a long (cold-trap) passage with adjoining niches. the coastal archipelago off the mouth of the Nuuk Fjord system (Fig. 1A). The ruin lies on a plateau only some 7 masl (Fig. 8) and is sheltered and little visible from all directions except if approached from the open Davis Strait to the southwest. Prior published descriptions are Berglund (1973), Gulløv (1983), and McGovern (1979). The author had the opportunity to survey the site on November 3, 2017.

The ruin appears roughly rectangular with external measurements of $\sim 4.0 \times 1.7 \mathrm{~m}$ and is fairly collapsed (Fig. 8 and 9). The southern end, however, preserves "a chamber" (or gable) built as single-skin (Type 3a) dry-stone wall, only $\sim 40-50 \mathrm{~cm}$ wide, made from flattish stones stacked with no apparent order up to 12 intact courses high ( 1 m). This stonework was never stable enough to support a roof, and neither is there enough surrounding collapse stone for the walls ever to have stood much higher.

Because of distance, sparse vegetation, and lack of substantial freshwater sources, terrestrial shieling use of Mitsimmavissuaq islet is inconceivable. Instead, the feature has been suggested as a Norse marine shieling related to the rich coastal wildlife (e.g., a skemma, Gulløv 1983), perhaps as a depot for storing seabirds and marine mammals in connection with outer fjord provisioning or travels to the Norðrsetr (Berglund 1973), or even

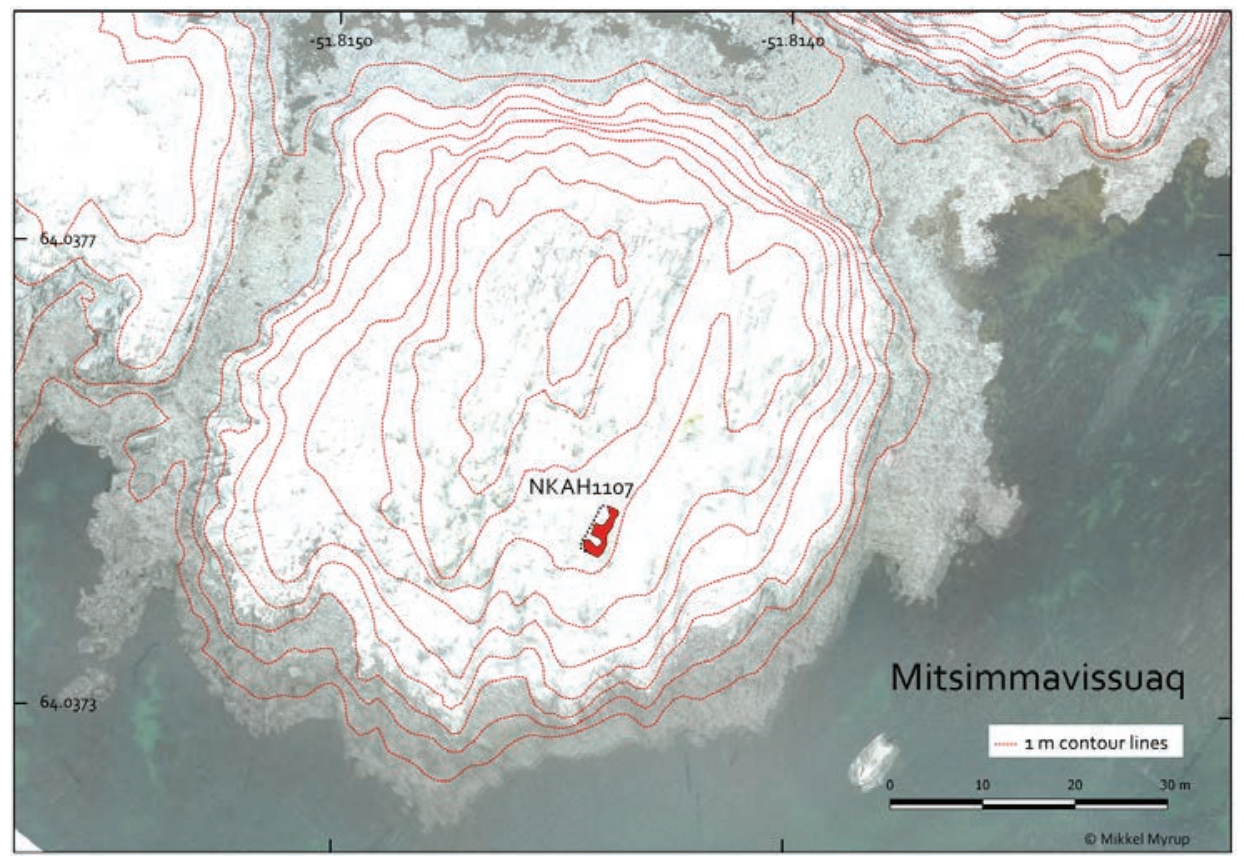

Figure 8. Detail survey plan of the suggested Norse feature at NKAH 1107, Mitsimmavissuaq (figure created by Mikkel Myrup, 2018). 


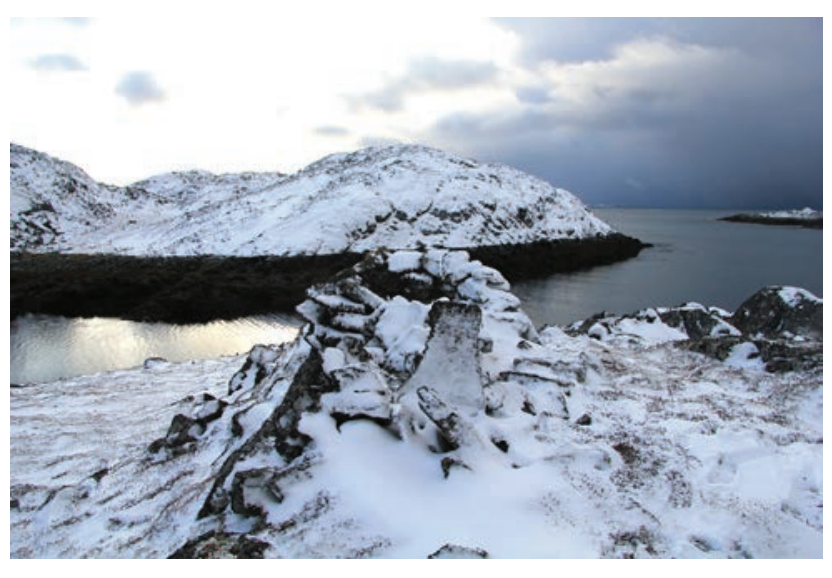

Figure 9. A recent image of the suggested Norse feature at NKAH 1107, Mitsimmavissuaq, looking southwest. In the upper right, skerries at the edge of the open Davis Strait are visible (photographed by the author in 2017).

a marine-hunting station (McGovern 1979). However, the feature's architectural character and microtopographic setting (see Table 1 and 2) suggest that it was not Norse but more likely a shooting blind or shelter (Inuit origin?) (Gulløv 1983), possibly superimposing and reusing elements of an older turf-and-stone built, non-Norse feature.

\section{NKAH 1417 (M20), Naajaat, Qeqertarsuatsiaat Kangerluat, $63^{\circ}$ Latitude:}

The site includes four Norse ruins occupying a reasonably sheltered small plain at the foot of 500-600 m high mountains in Qeqertarsuatsiaat Kangerluat (Fiskenæs Fjord, Fig. 1A). Prior site descriptions used here are Albrethsen and Arneborg (2004), Bruun (1918), and Pingel (1832).

The larger two Norse ruins (Fig. 10), ruins $a$ and $b$ are both described as rectangular, Ruin $a$ externally measures $\sim 13.5 \times 5.0 \mathrm{~m}$ and Ruin $b$ $\sim 20.0 \times 6.5 \mathrm{~m}$ (Table 2). An 1829 survey describes the walls as poorly preserved (Pingel 1832:103), whereas 1903 fieldnotes mention walls made of "stone and some turf" in Ruin $b$ preserved to a height of up to $\sim 1.1 \mathrm{~m}$ (Albrethsen and Arneborg 2004:72). A perspective drawing from the same survey displays walls standing to below knee height (Bruun 1918:Fig. 36). The combined evidence suggests that both buildings had Type 1 walls raised on multicourse stone foundations (Table 2), which is supported by 1952 ruin sketches (Albrethsen and Arneborg 2004:Fig. 124 and 125). Ruin $a$ had two entrances on its northern wall, while Ruin $b$ had only one entrance on its southern wall, several internal divisions or rooms, as well as an annex to the north. 1829 and 1952 test excavations inside and outside the features

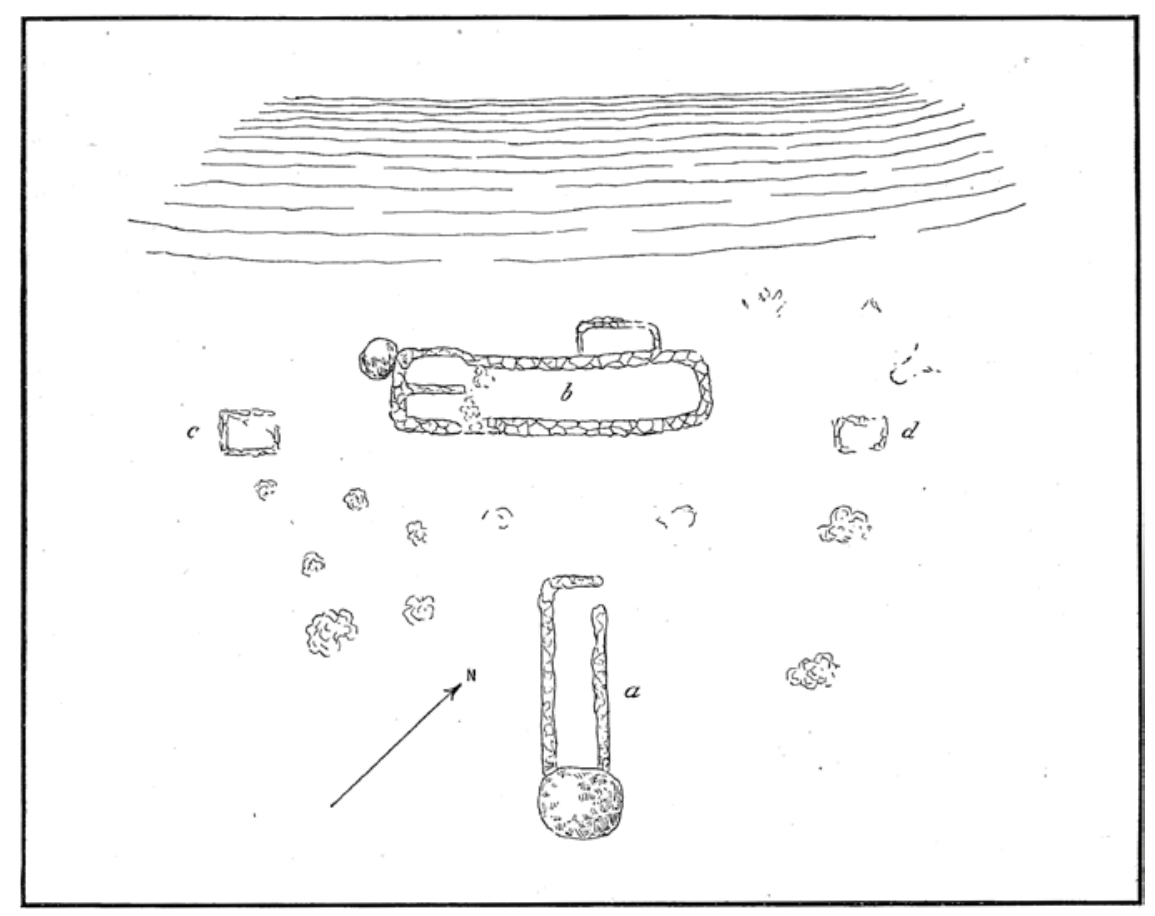

Figure 10. Site sketch overview plan of Norse site NKAH 1417 (M20), Naajaat. Ruins $a$ and $b$ are described and discussed in detail in the text (after Bruun 1917:Fig. 35). 
revealed no finds or cultural deposits (Albrethsen and Arneborg 2004; Pingel 1832).

Surrounded by poor, shrub-dominated pastureland (Bruun 1918; Pingel 1832), and counting only four ruins with no trace of a home field, midden, or other cultural deposits, Bruun (1918:108) was surely correct in observing that NKAH 1417 was never a Norse farmstead proper. Instead, he suggested that the site was a "terrestrial" summer shieling and interpreted all four features as sheep and goat pens. However, the nearest known Norse farmsteads are NKAH 1416 at $\sim 86 \mathrm{~km}$ to the north and NKAH 458 at $185 \mathrm{~km}$ to the south. In contrast, normal maximum farm-to-shieling distances in the outer fjord Eystribyggð are $10 \mathrm{~km}$ (Madsen 2014b:Table 7.2). Thus, it must seem highly improbable that the Norse should have ferried livestock - and based on the size of the assumed pens in quite considerable number-such long distances to poor-quality pasturelands.

The slight possibility exists that NKAH 1416 was a satellite to a still-undiscovered, nearby farmstead or that the site served to round up free-roaming sheep and goats. However, considering the insulating build of the walls of Ruin $a$ and $b$ (Table 2), the site is more plausibly interpreted as either as a short-lived attempt at establishing a remote farmstead or a temporary habitation for a group of people (i.e., a specialized or provisional basecamp in the óbyggðir). Resources in NKAH 1416's environs include good caribou-hunting grounds, char rivers, a large seagull colony on an island $\sim 3 \mathrm{~km}$ southwest, and nearby spring iceedge hunting for ringed seal (Bruun 1918).

\section{NKAH 1415 (M19), Eqaluit, Allumersat (Bjørnesund), $62^{\circ}$ Latitude}

NKAH 1415 (M19) includes three to six Norse ruins occupying a sheltered, but somewhat shaded, setting at the head of an inlet by a bend of the Allumersat Fjord (Fig. 1A and 11). Prior site investigations used here are Albrethsen and Arneborg (2004), Bruun (1918), Jensen (1879), and Pingel (1833).

The largest ruin is described as rectangular with external measurements of $18.9 \times 6.3 \mathrm{~m}$, with (Type 1, Table 1) turfs walls $\sim 1.6 \mathrm{~m}$ wide and preserved to a height of $\sim 0.6 \mathrm{~m}$. Two entrances were on the long eastern wall, but no room divisions were observed. Further, two to five ruins may have existed in the surroundings, but only two have been confirmed (Bruun 1918). Unspecified 1838 and 1878 excavations both inside and outside the main feature ruin only yielded some charcoal (Jensen 1879; Pingel 1833).

NKAH 1415 is interpreted as a specialized or provisional basecamp for Norse mariners or hunters in the óbyggðir on the same criteria as NKAH 1416: great distance to nearest farmstead;

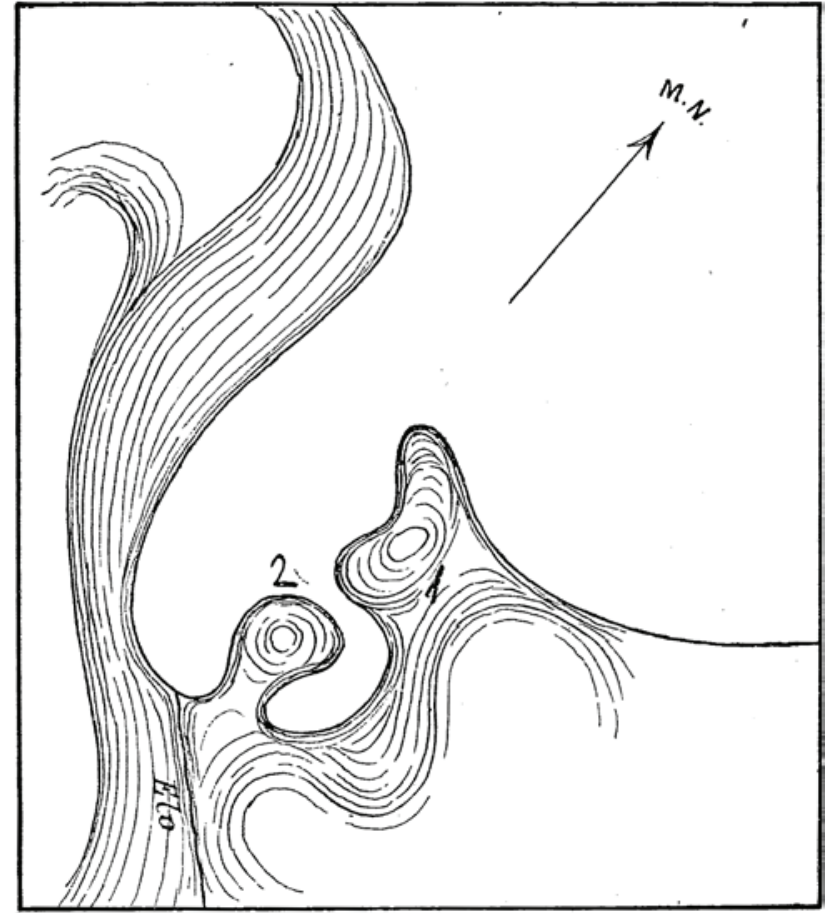

Figure 11. Site sketch plan overview plan of Norse site NKAH 1415 (M19), Eqaluit. No. 1 shows the setting of the Norse ruins described in the text; No. 2 a Thule culture or later Inuit summer fishing camp (after Bruun 1917:Fig. 39)

poor-quality pastureland (Bruun 1918; Pingel 1833); few recorded buildings, at least one of them of a size and built to facilitate habitation, including cold-period (Table 2), for several people; absence a home field or a midden area; and with only very slight cultural deposits.

\section{NKAH 5558, Qajartalik, Arsuk, 61 Latitude}

The site includes one probable Norse ruin sited on an exposed plateau on the eastern side of the small and barren island Qajartalik $\left(\sim 0.2 \mathrm{~km}^{2}\right)$, which is separated from the mainland by a strait $\sim 800 \mathrm{~m}$ wide (Fig. 1A and 12). The site was reported to the author by geologists from the Geological Survey of Denmark and Greenland (Karsten Secher, personal communication 2009) and has not been published before, although a nearby Thule culture winter settlement (NKAH 472) is recorded (Fig. 12) (Albrethsen et al. 1990). The below description is based on photos and Google Earth satellite imagery. The ruin appears square of shape with estimated external measurements of $\sim 3.8 \times 3.7 \mathrm{~m}$, dry-stone walls $\sim 0.8-1.2 \mathrm{~m}$ wide, and featuring all the characteristics of Norse Type 3c stone architecture, including heavy cornerstones in three corners 


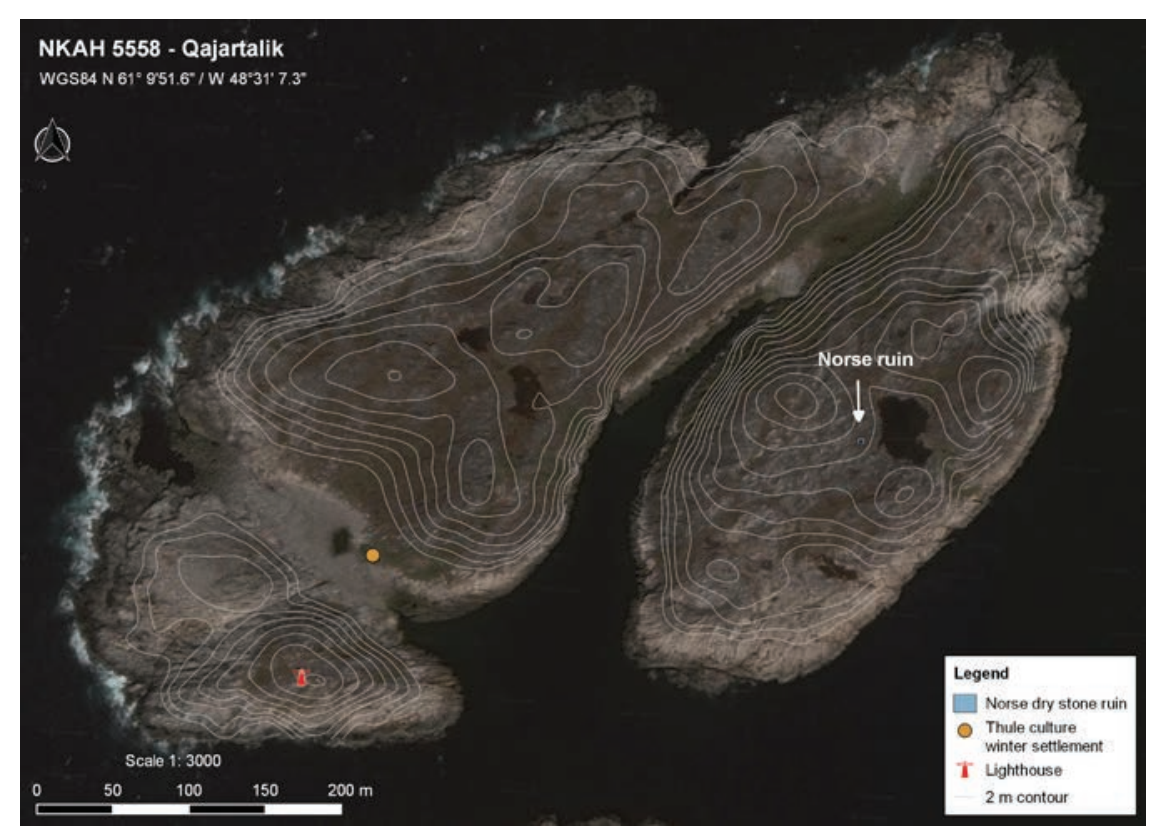

Figure 12. Site overview plan on Google Earth satellite imagery (V. 7.1.8.3036, November 8, 2015, DigitalGlobe 2019. http://www.earth.google. com) of Norse site NKAH 5558, Qajartalik. The plan also shows the location of a nearby Thule culture winter settlement and the modern, unmanned lighthouse (figure compiled by the author).

(Table 1; Fig. 13). The walls appear preserved to a height of $\sim 1.5 \mathrm{~m}$ (9-10 courses), and substantial amounts of surrounding collapse stone suggest that they would originally have stood higher. A narrow doorway is located on the middle of the buildings southern wall, with a threshold raised slightly above the bedrock floor so that one steps down into the interior. Another unusual detail is what appears a small opening or window on the wall opposing the doorway.

Displaying the architectural characteristics of all Type 3c dry-stone wall (Table 1), NKAH 5558 most likely represents the remains of a Norse building, although a later historical European origin cannot be excluded. The building's wall material and building ground preclude prolonged cold-period habitation (Table 1 and 2). These factors, combined with a very wind exposed setting and nearby excellent landing conditions (Fig. 12; Table 2 and 3), suggest that the site could have been a marine waystation similar to NKAH 3630, if not a seasonal (summer-half of the year) marine-hunting station to Norse farmstead NKAH 440 (M11) 3.7 km east or to the wider local Norse community in the area.

\section{NKAH 2329 (Ø148), Ilorru, Itillinguaq, $61^{\circ}$ Latitude}

The site includes one or two Norse ruins located on a stony hillock beneath a steeply sloping

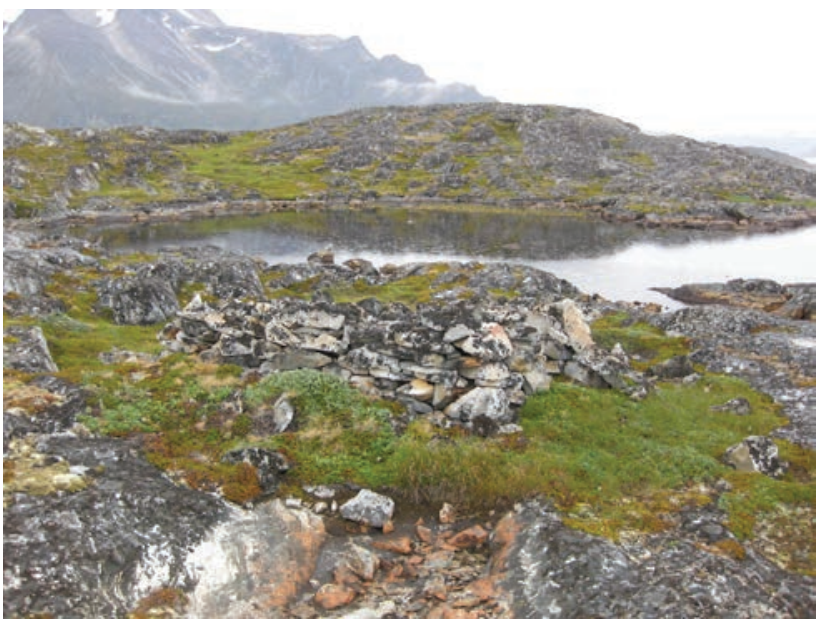

Figure 13. A recent image of the Norse ruin at NKAH 5558, Qajartalik, looking southeast. Note the fairly large building and cornerstones and use of "stone wedges" to level the wall's courses, all of which are architectural features characteristic of Norse building customs (photographed by Karsten Secher, 2009).

mountain hinterland (300-400 masl) on the northern side of the Itillinguaq Fjord, about halfway between the Eastern and Middle settlements (Fig. 1A). Prior site investigations were undertaken by Nørlund (1921). 


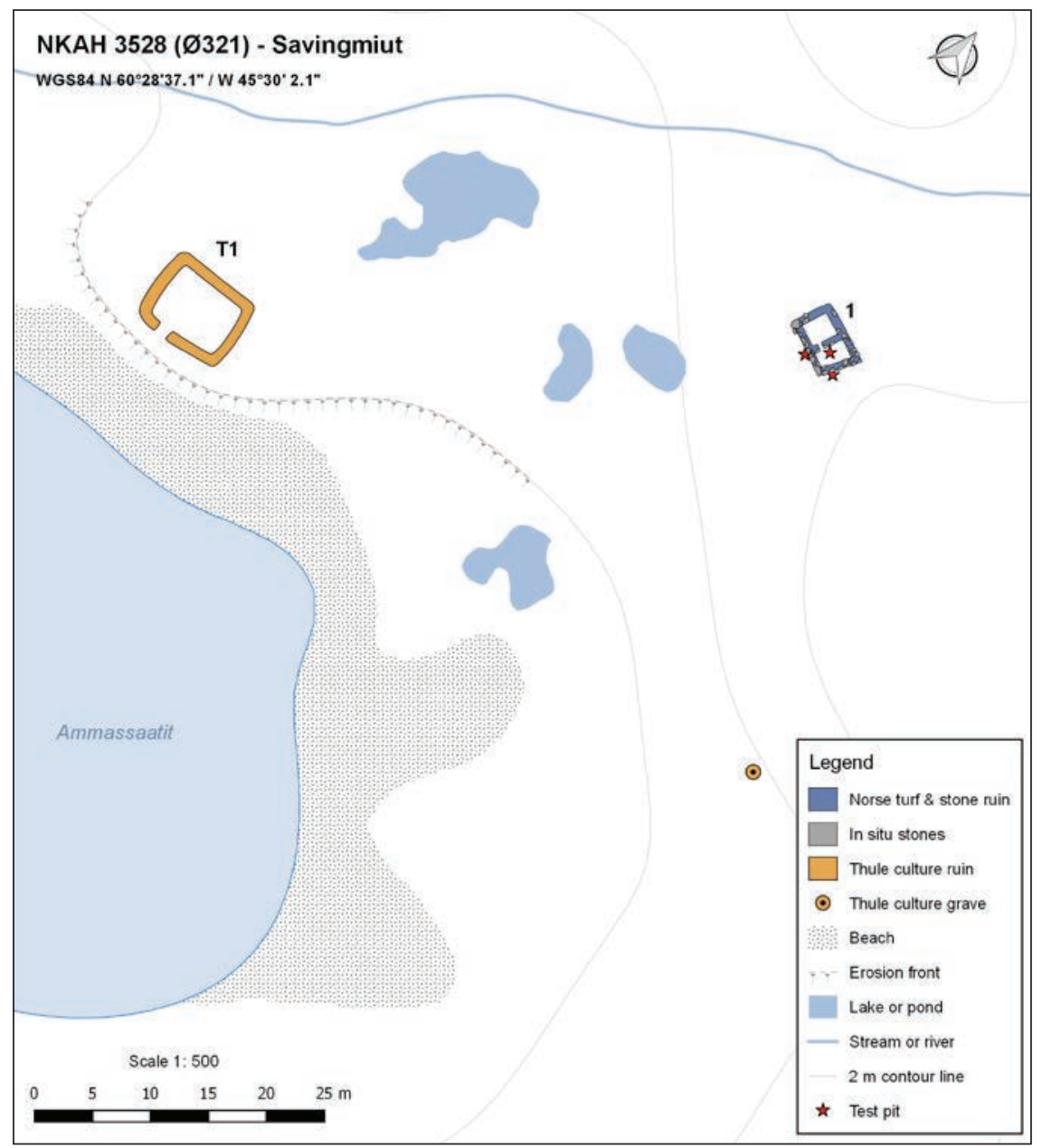

Figure 14. Site survey plan of NKAH 3528 (Ø321), Savingmiut, with indications of the possible Norse ruin and a later Thule culture winter house and smaller features, as well as the location of test pits excavated during the 2017 CIE/WiCP field campaign (figure created by the author).

The main feature-probably the remains of a dwelling-is described as completely collapsed, measuring $\sim 15 \times 12 \mathrm{~m}$, and built of turf and stone. Another possible ruin was observed $\sim 15 \mathrm{~m}$ southwest. Minor unspecified test excavation produced "no results of any value" (Nørlund 1921).

The poor quality of surrounding pastureland, lack of outbuildings, home field, midden or other cultural deposits exclude that NKAH 2329 was a farmstead. However, as also noted by Nørlund (1921), the site seems located too far away from the nearest farmstead-NKAH $2311 \sim 24 \mathrm{~km}$ to the east-to be a terrestrial shieling, which led him to suggest that site could have been the "refuge of a lawless person or the like." More likely the site functioned as a specialized/provisional basecamp like NKAH 1415 and 1417, with which it shares general geographic setting, resource access, and layout.

\section{NKAH 3528 (Ø321), Savingmiut, Akuliarutsit, $60^{\circ}$ Latitude}

The site includes one suggested Norse ruin situated on a small rocky outcrop by a bay on the northern side of the tip of the peninsula between the Alluitsup- and Uunartup Kangerlua (Fig. 1B and 14). A nearby Thule culture winter house and many associated stone features will not be discussed here. NKAH 3528 was located by local school teacher Ove Bak in 1971 (Bak 1972) but not revisited by archaeologists until during the CIE/ WiCP 2015 and 2017 field campaigns. In 2015, the ruin was DGPS-surveyed and surface recorded; in 2017, three 0.5- $\times-0.5-m$ trenches-one inside and two outside the ruin-were excavated (Fig. 14).

The supposed Norse feature is rectangular with external measurements of $5.5 \times 3.8 \mathrm{~m}$, divided into two rooms, and with a well-preserved 


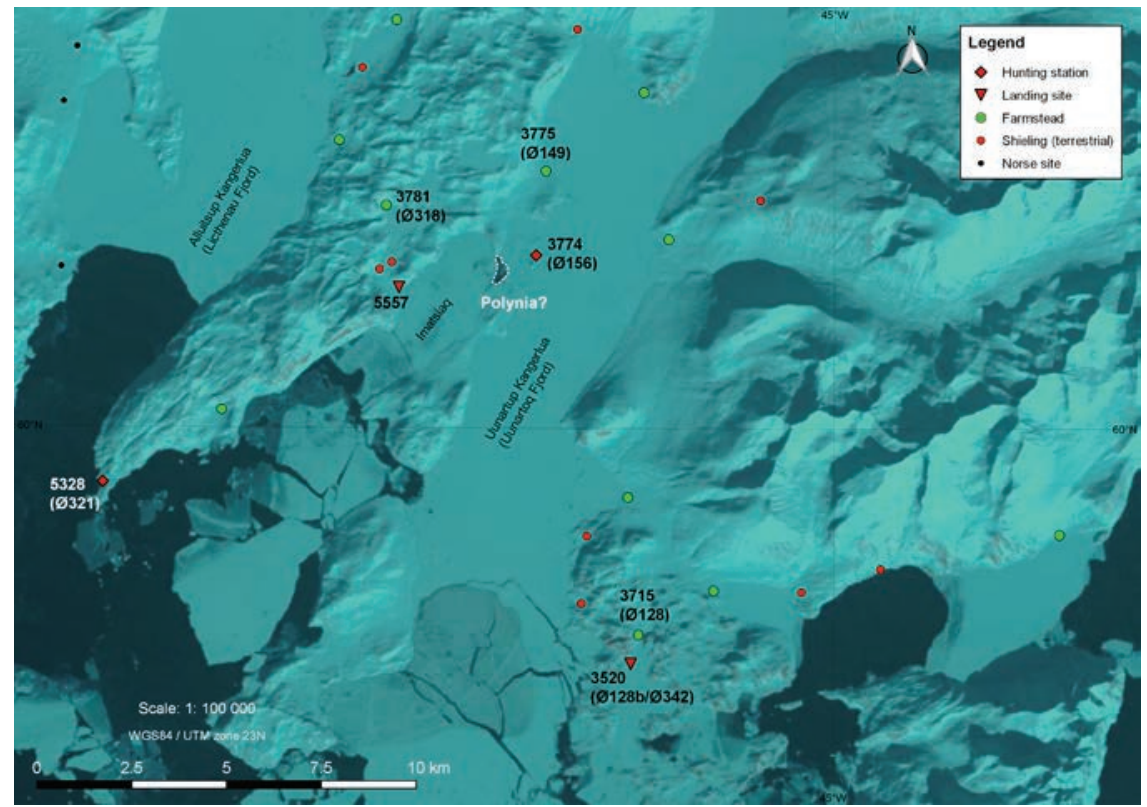

Figure 15. Wintertime (March 27, 1993) LT05 Landsat satellite imagery (credit: U.S. Geological Survey, USGS. https://landsatlook.usgs.gov/viewer. html) of the middle CIE/WiCP study area with indication of marine shielings, farmsteads, and terrestrial shielings, as well a possible small polynya near NKAH 3774 (Ø156). Farmsteads mentioned in the text are numbered.

Type 2 wall double-row stone foundation (Table 1) $\sim 0.5-0.9 \mathrm{~m}$ wide. Limited amounts of collapse stones are seen, the ruin's western half having wider walls and more collapse stone than the eastern half. The stonework is made from angular, medium-sized stones and does not appear distinctly Norse, which raises a concern also voiced by Bak (1972) that it could be a ruin of a later historical building?

The three test pits excavated in 2017 (Fig. 14) all revealed very shallow $(<20 \mathrm{~cm})$ stratigraphies with hardly any cultural inclusions. However, in the easternmost test pit, a thin horizon with a few bits of charcoal was observed just above the bedrock. Charcoal samples from this layer were speciated as pine and heather (Susan Ramsay, personal communication 2017) but an attempt to date the latter sample (SUERC-77463) came back with a fraction value indicative of nuclear era (post-AD 1950) (i.e., would seem a later disturbance). A piece of window glass in another test pit also implies some recent activities.

If NKAH 3528 is a Norse site, a terrestrial shieling function is disqualified by its setting on the very sparsely vegetated and much wind exposed Akuliarutsit headland that projects out into open ocean and, in spring and summer, floes of drift ice. Contrariwise, this setting at the strong-current cross-over between two fjords (Fig. 1B and 15) sustains very rich marine wildlife. With Type 2 insulating turf-and-stone walls and a sheltered setting, the building must have facilitated habitation, although the bedrock building ground, limited wall widths, and thin cultural deposits preclude prolonged (cold-period) occupancy. Instead, NKAH 3528 could have been a temporarily occupied marine-hunting station, perhaps under Norse farmstead NKAH 3525 (Ø157) $\sim 4 \mathrm{~km}$ to the north or serving a couple of farms in the fjords. Alternatively, the feature is the remains of a late historical sod-and-stone house.

\section{NKAH 5557, Kuuk, Uunartup Kangerlua, $60^{\circ}$ Latitude}

The site includes one sheltered Norse ruin cut slightly into a gravel shelf just above the shore and at the foot of gently sloping low mountains (100 masl) on the northern side of the Imatsiaq Strait, about one third into the Uunartup Kangerlua (Fig. 1B, 15, and 16). The site was located by Bak (1972a) in 1967-1968 but not subsequently revisited until the CIE/WiCP 2015 field campaign, during which the ruin was DGPS-surveyed and surface recorded. Nearby Inuit summer-camp features are not discussed here. 


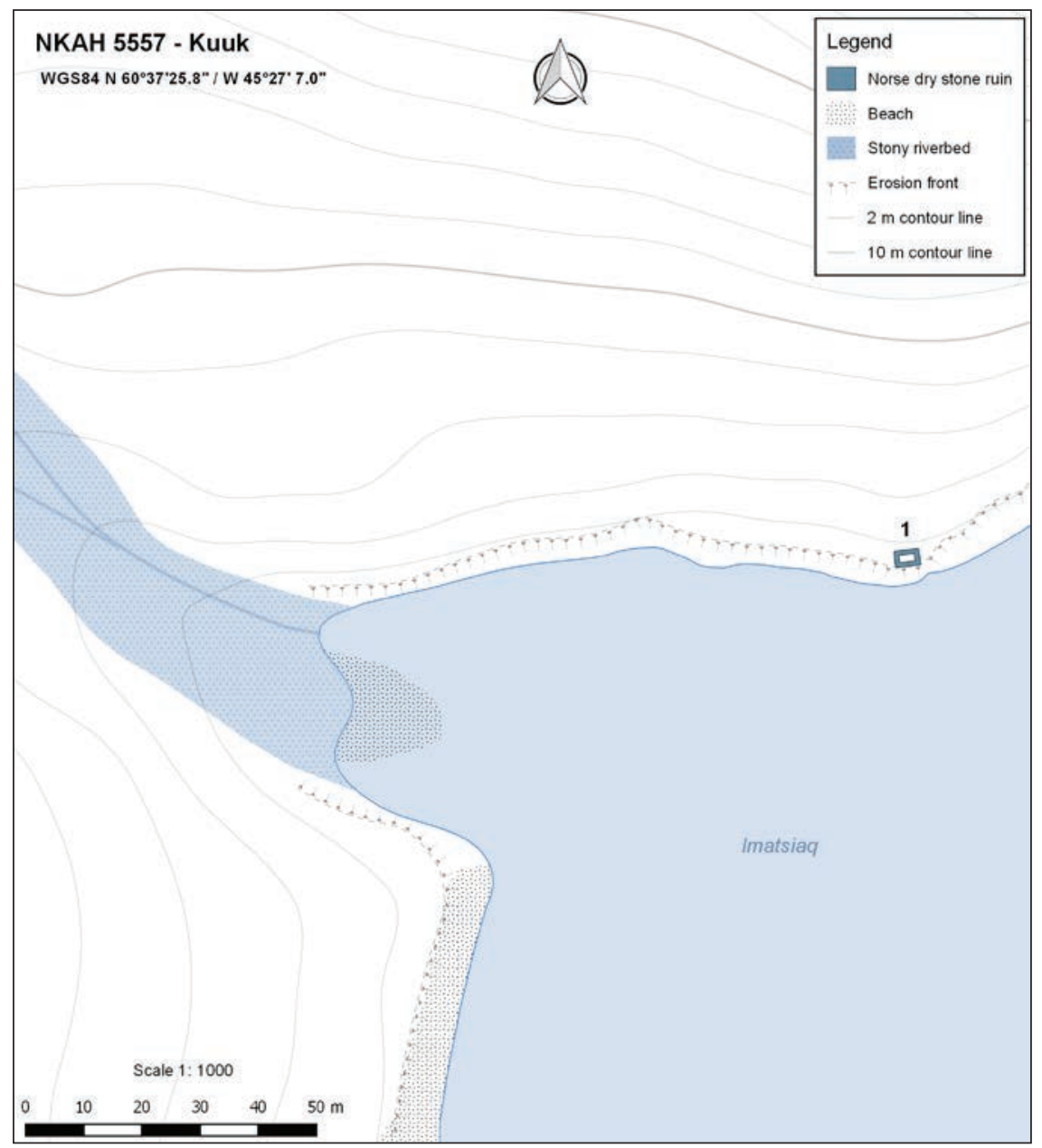

Figure 16. Site survey plan of NKAH 5557, Kuuk, with indications of the Norse ruin and nearby Kuuk River (map created by the author).

The ruin is rectangular with external dimensions of $\sim 4.4 \times 2.9 \mathrm{~m}$ (Fig. 16). Although heavily collapsed, it is still possible to observe Type $3 \mathrm{~d}$ (Table 1) double stone walls $\sim 0.8-0.9$ m wide, made from large rounded stones, and with a heavy northwest cornerstone. The western gable is still preserved to a height of $\sim 1 \mathrm{~m}$ (three to four courses). Large numbers of collapsed stone imply that it was a building raised completely in dry stone.

NKAH 5557 was probably a satellite to the sizable NKAH 3781 farmstead located $\sim 2 \mathrm{~km}$ inland to the north (Fig. 15). With a dry-stone build, located near fjord but still in a fairly sheltered setting, neither habitation nor ventilation was the primary function of the building (Table 2 and 3) (i.e., it is unlikely to have served terrestrial shieling functions). Instead, it is suggested that NKAH 5557 was a sturdy and dry storage structure for tools and equipment used by the fjord (i.e., a marine-landing site to farmstead NKAH 3781).

\section{NKAH 3774 (Ø156), Qajartalik, Uunartup Kangerlua}

NKAH 3774 includes two Norse ruins located on the northern tip of the small island Qajartalik $\left(\sim 0.7 \mathrm{~km}^{2}\right)$ about halfway into, and on the western side of, the Uunartup Kangerlua (Fig. 1B and 15). Both features lie just above a small stony beach, the extremely sheltered and partly shaded Ruin 1 being dug slightly into a gravel surface against a low vertical cliff, whereas Ruin 2 lies on a more exposed gravel terrace just $20 \mathrm{~m}$ northwest (Fig. 17), where it receives both more wind and sunlight. Prior site descriptions are Bak (1972) and Vebæk (1968). NKAH 3774 was visited twice during the CIE/WiCP field campaigns: in 2015, 


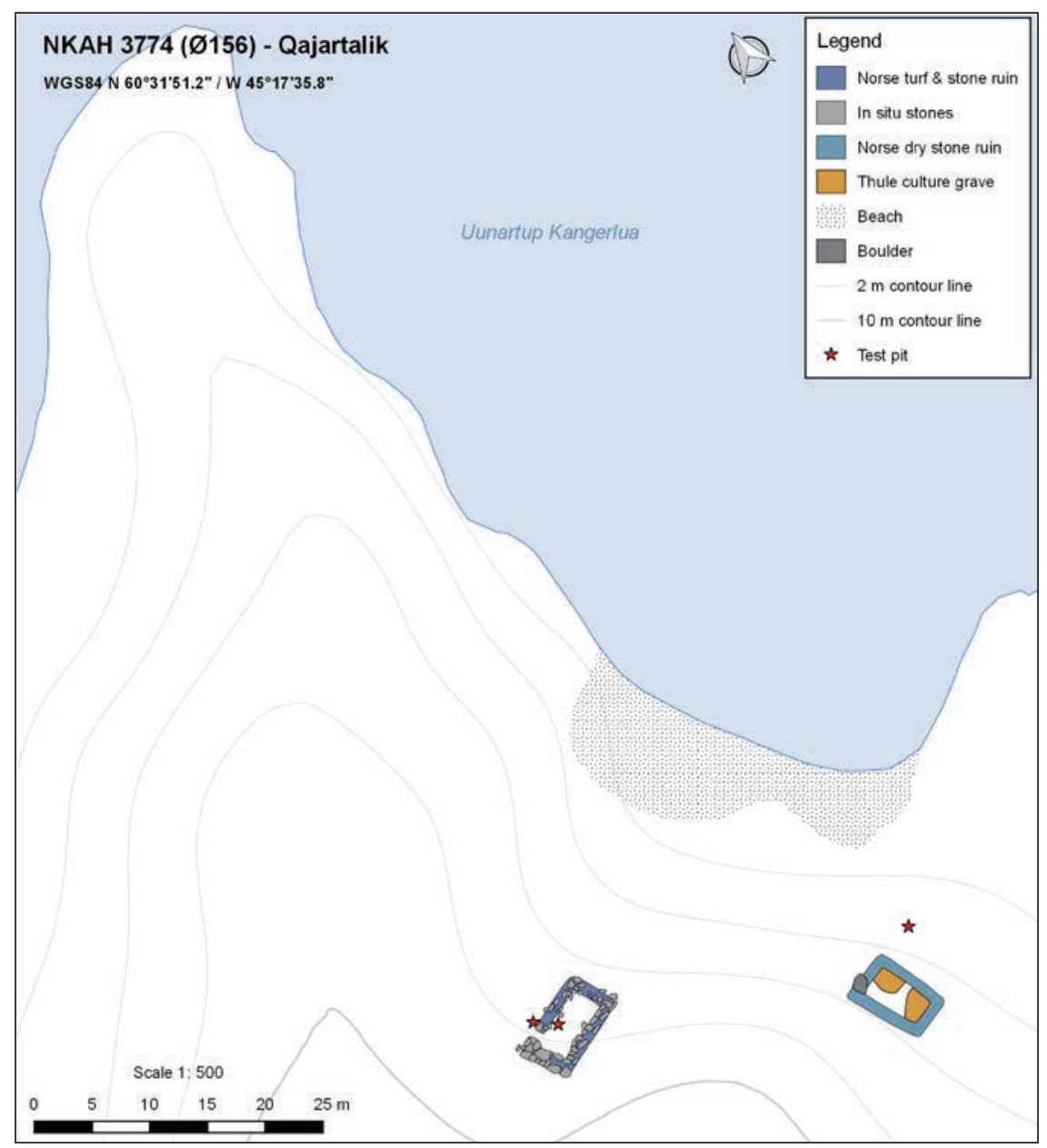

Figure 17. Site survey plan of NKAH 3774 (Ø156), Qajartalik, showing the two Norse ruins, Inuit graves inside Ruin 1, as well as the location of test pits excavated during the $2017 \mathrm{CIE} / \mathrm{WiCP}$ field campaign (map created by author).

the ruins were DGPS-surveyed and surface recorded; in 2017, three 0.5-x-0.5-m trenches-one inside and two outside the ruin-were excavated (Fig. 17).

Both ruins are well-preserved, rectangular, of similar size (Fig. 17) but of very unlike build: Ruin 1 measures $\sim 7.4 \times 4.8$ externally and has Type 3d double dry-stone walls $\sim 0.9-1.2 \mathrm{~m}$ wide (Table 1 and 2), preserved to a height of $\sim 1.2 \mathrm{~m}$ (four heavy courses), and with massive cornerstones. Judging from the amount of collapse stone-part of which has been reused to construct Thule culture burials inside the feature-Ruin 1 originally had walls standing at least $1.5 \mathrm{~m}$ high. Ruin 2 has external measurements of $\sim 8.0 \times 4.7$ and Type 1 walls (Table 1 and 2) preserved as an almost intact double-row stone foundation $\sim 1.0-1.4 \mathrm{~m}$ wide in one to two courses. A doorway $\sim 0.6 \mathrm{~m}$ wide is in the ruin's northwestern corner. Hardly any collapse stone is visible but neither is turf or grass, and the wall's turf superstructure thus appears to have completely disintegrated.

The three test pits excavated in 2017 (Fig. 17) all revealed very shallow $(\sim 15-30 \mathrm{~cm})$ stratigraphies with few cultural inclusions. However, in one test pit, a thin vegetation horizon with three pieces of charcoal was discovered just above natural gravel. The charcoal sample was speciated as pine (Susan Ramsay, personal communication 2017). Although clearly driftwood, one sample (SUERC-77462) was dated to exclude a recent origin of the features perhaps, yielding a calibrated age (OxCal v4.3.2., IntCal 13 atmospheric curve) of AD 1222-1280 $(2 \sigma)$, confirming the sites Norse origin.

Noting Qajartalik's extremely poor grazing potential and lacking freshwater sources, it is suggested that NKAH 3374 was a Norse marinehunting station, where the insulated turf building (Ruin 2) facilitated temporary, including 


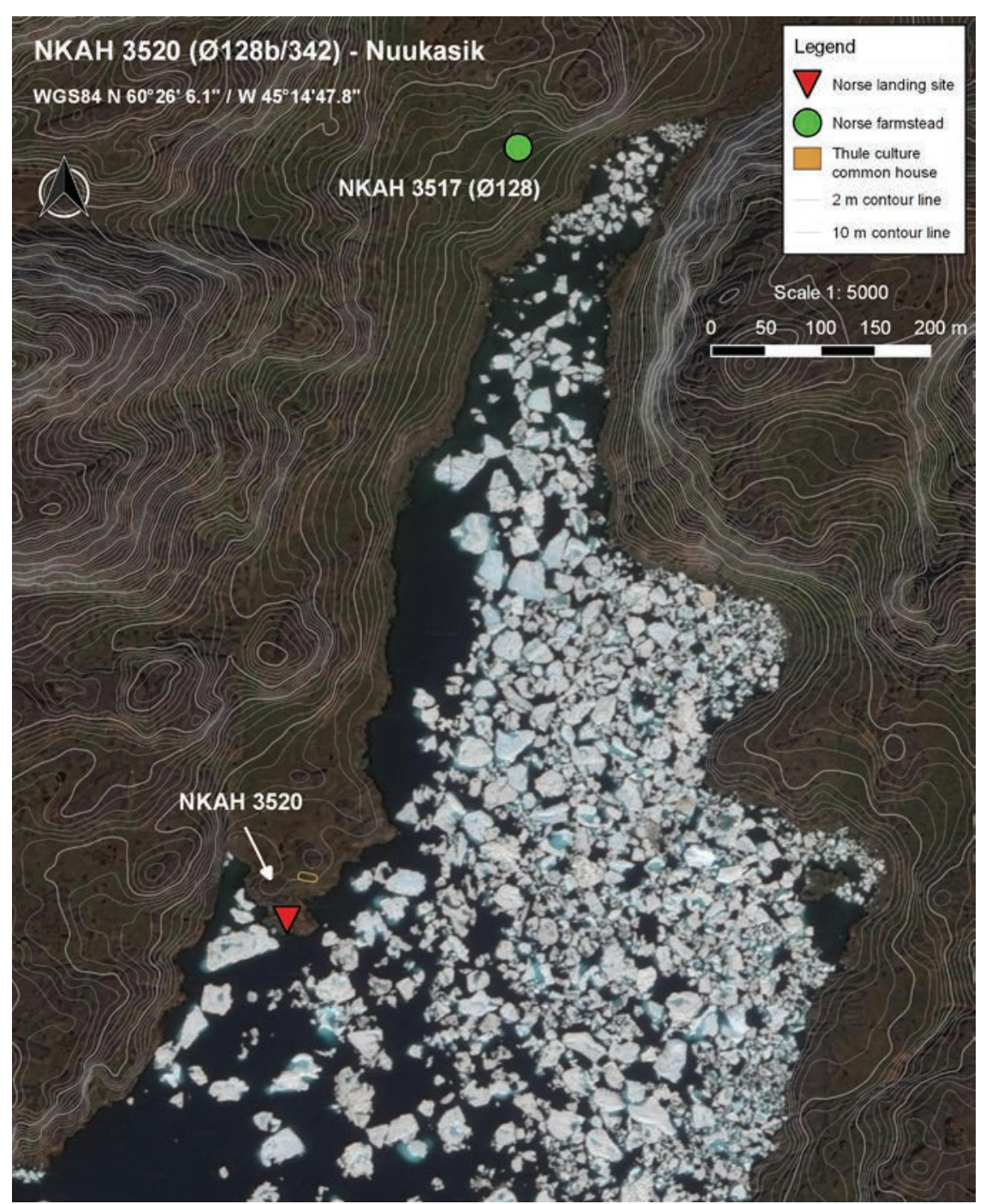

Figure 18. Site survey plan on Google Earth satellite imagery (V. 7.1.8.3036, July 2. 2014, DigitalGlobe 2019. http://www.earth.google.com) of NKAH 3520 (Ø128b/Ø342), Nuukasik, with indications of the nearby Norse farmstead NKAH 3717, the later Inuit settlement of Qunnermiut. As seen in the imagery, drift ice clutters the inlet with the farmstead and settlement, making NKAH 3520 a more optimal landing site.

cold-period, habitation for hunters, while the sheltered stone building (Ruin 1) served as marine tool and equipment store (Table 2 and 3). Qajartalik is part of an ice barrier at the head of the Imatsiaq Basin, where masses of summer drift ice is trapped and creates a cold microenvironment rich in seal and today still serving as favored summer hunting grounds for local Inuit from the Alluitsup Paa settlement. During the winter half of the year, the marine shieling may have served to ease hunting from the fjord's ice edge or by a nearby small polynya indicated by satellite imagery (Fig. 15).

\section{NKAH 3520 (Ø128b/Ø342), Nuukasik, Qunnermiut Ikerasaat, $60^{\circ}$ Latitude}

NKAH 3520 includes one Norse ruin located on a spit of bedrock on the western shore of the sheltered basin Qunnermiut Ikerasaat between the fjords of Uunartup Kangerlua and Sermilik (Figure 1B, 18). Prior site investigations are Albrethsen (1971) and Bak (1972) The site was DGPS-surveyed and surface recorded during the 2014 WiCP/CIE field campaign (Fig. 18 and 19). Nearby Thule culture features will not be discussed here. 


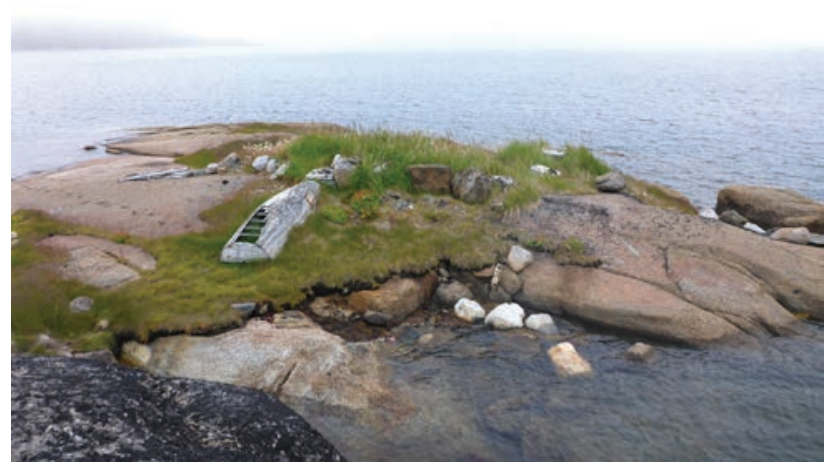

Figure 19. Photo looking southeast towards the small outcrop with the ruins of landing site NKAH (Ø128b/ Ø342) and the remains of a dinghy once used by local Inuit from the nearby settlement of Qunnermiut (photographed by the author in 2014).

The Norse ruin is highly disturbed by a recent stone and concrete Inuit boathouse (Fig. 19) but can be partly reconstructed from the remaining foundations combined with 1971 photographs from the Danish National Museum archives. The Norse feature was a rectangular building with external dimensions of $\sim 4.2 \mathrm{~m}$ by at least $5 \mathrm{~m}$ and a heavy double-row Type $3 \mathrm{~d}$ wall foundation, measuring $\sim 0.9 \mathrm{~m}$ wide and preserved in one course (Table 1-2). Collapsed stone lying around the cliff and reused in the later Inuit boathouses supports that it was originally a dry-stone building.

NKAH 3520's ruin is interpreted as a marine tool-and-equipment store (i.e., a site serving as a landing site to nearby Norse farmstead (NKAH 3517 (Ø128)) situated $\sim 700 \mathrm{~m}$ north, where there are also the considerable remains from the Thule culture and the later Inuit settlement of Qunnermiut - a testimony to the rich marine wildlife of the area. However, as the narrow and shallow inlet by Qunnermiut itself is liable to freeze or get clocked by drift ice, both the Norse and later Inuit site was placed to ensure better access to open fjord waters (Fig. 18 and 19).

\section{NKAH 4468, Kangeq, Sermersooq, $60^{\circ}$ Latitude}

NKAH 4468 includes one certain and two or three possible Norse ruins located on a sheltered, gravelly terrace at the foot of steep mountains on the southern tip of Sermersooq Island (Fig. 1B and 20). A prior site description was made by Raahauge et al. (2002). The two or three possible Norse features are to be located by a Thule and later Inuit settlement (NKAH 3611) 700 $\mathrm{m}$ to the west but were not noticed during other surveys (Bak 1971; Mathiassen and Holtved 1936). Neither were they found during the $2016 \mathrm{WiCP} / \mathrm{CIE}$ field campaign, at which time Ruin 1 was DGPS-surveyed and surface recorded, and three test pits excavated (Fig. 20).

The fair-sized Ruin 1 is rectangular with external measurements of $\sim 22.0 \times 10.5 \mathrm{~m}$ and well-preserved $\sim 1.1-1.5 \mathrm{~m}$ wide Type 1 turf walls (Table 1 and 2) that outline at least seven rooms: three central rooms lie in a linear arrangement with additional rooms added to both sides (Fig. 19). Three 2016 test pits revealed no traces of midden deposits or manuring of a possible homefield area.

Situated in very poor pastureland without home field, midden deposits, or adjacent outbuildings, but presenting a heavily insulated, sizable building, NKAH 4468 is interpreted as a Norse specialized/provisional basecamp for a group of people, who most likely were hunting crews engaged in seasonal hunting on migratory seal species that pass close to the tip of Sermersooq. The richness of this marine environment is attested by the nearby Thule and later-Inuit site of Kangeq (NKAH 4468), which even today serves as an important Inuit marine-hunting camp.

\section{Norse Marine Shielings in East Greenland}

$$
\begin{gathered}
\text { NKAH } 1506 \text { (Ø117), “Rolf's } \\
\text { Ruin,” Narsaq, Kangerlussuatsiaq } \\
\text { (Lindenow Fjord), } 60^{\circ} \text { Latitude }
\end{gathered}
$$

NKAH 1506 includes one, perhaps two, Norse ruins located $\sim 16 \mathrm{~km}$ into, and on the northern side of, the $60 \mathrm{~km}$-long deep Narsaq, Kangerlussuatsiaq in East Greenland (Fig. 1A and 21). The larger ruin occupies a fairly sheltered setting on the upper edge of a gravelly plain at the foot of a mountain slope $\sim 100 \mathrm{~m}$ from the shore, while a small animal pen is located a bit higher on the slope. Prior investigations at the site include Bendixen (1929), Brodbeck (1882), Giesecke (1825), Holm (1889), Mathiassen (1936), and Nørlund (1932a,b), as well as notes and a photo from a nonscientific expedition in 1982 (Andersen 1982:271, 2006).

The main ruin is described as rectangular with external measurements of $\sim 28 \times 9 \mathrm{~m}$ and with Type 1 turf walls preserved only as $\sim 1.0 \mathrm{~m}$ wide foundation of extremely heavy foundation stones (Table 1 and 2) (Andersen 2006:271; Nørlund 1932b). Existing survey plans display the ruin as divided on at least three rooms and heavily disturbed by later Thule culture winter houses (Fig. 22) (Bendixen 1929:167).

Bendixen (1929) was undoubtedly right in concluding NKAH was not a farmstead but rather 


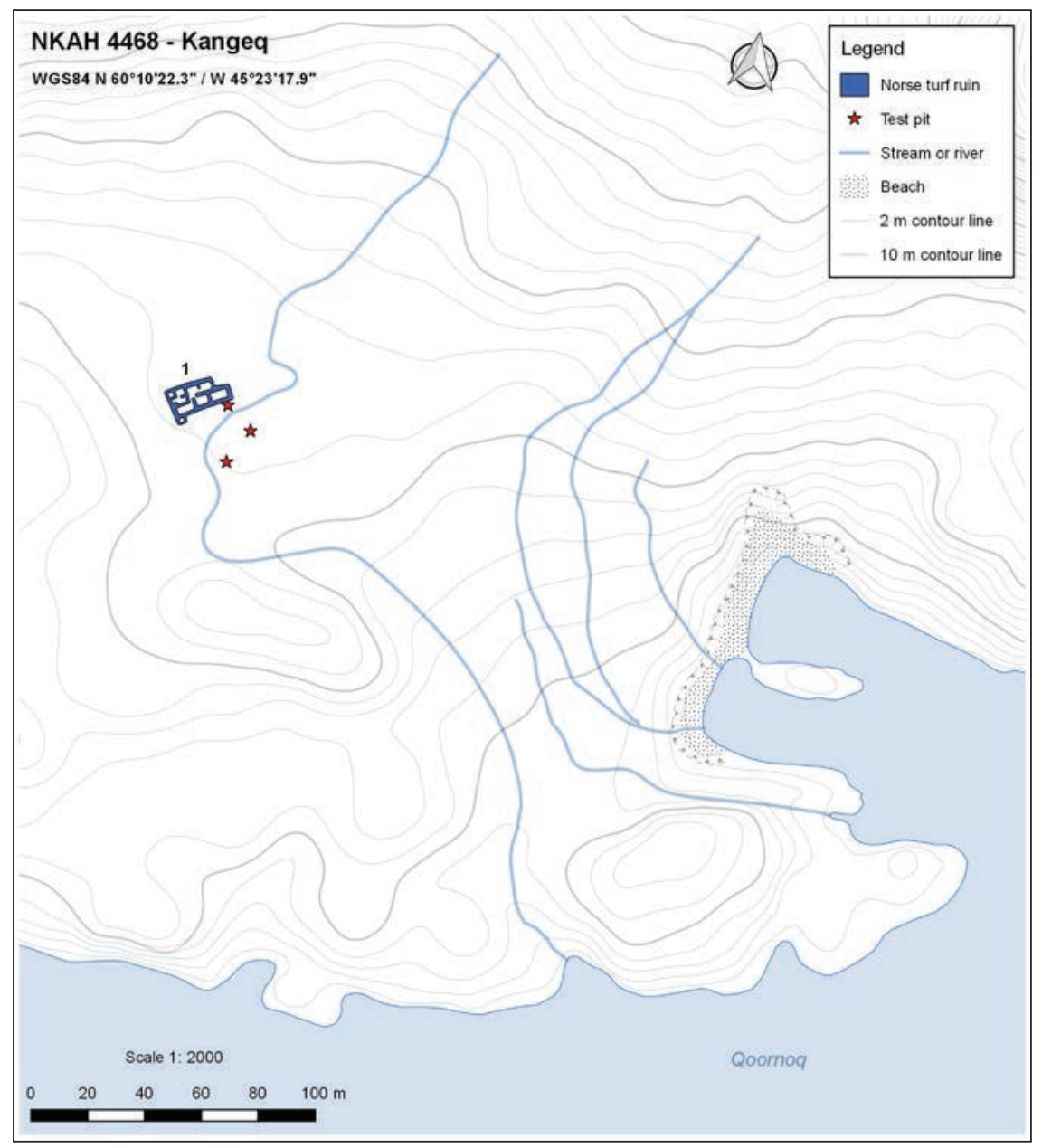

Figure 20. Site survey plan of NKAH 4468, Kangeq, showing the Norse ruin, as well as the location of test pits excavated during the $2017 \mathrm{CIE} / \mathrm{WiCP}$ field campaign (map created by the author).

some form of temporary site, an interpretation that is supported based on the site's remoteness; lack of outbuildings, a home field, and midden or refuse deposits; and poor-quality pastureland. Being a sizable feature, with thick Type 1 insulating walls, the building could have served as a specialized/ provisional marine basecamp used by Norse hunting crews during their trips to Greenland's east coast. The presence of a single sheep pen need not conflict with such an interpretation, as they could have easily brought a few sheep/goats on the seasonal but probably months-long hunting trips.

NKAH 3304, Iluillup Qeqertaa, Iluileq (Dannell Fjord), 60 Latitude:

NKAH 3304 includes one unconfirmed Norse ruin that lies among Thule and later-Inuit features by a bay on the southern side of the small island of Iluillup Qeqertaa $\left(0.19 \mathrm{~km}^{2}\right)$, which sits in an archipelago at the mouth of the fjord Iluileq (Fig. 1A). Prior site descriptions include Gulløv (1999), Holm (1889), and Mathiassen (1936), but only Andersen (1982) reports the possible Norse feature.

The ruin is described as a rectangular feature with measurements of $\sim 5.0 \times 4.0 \mathrm{~m}$, built of very large stones, and heavily overgrown with willow (Table 2) (Andersen 1982). Despite an intensive surface search, no tools were found.

Lacking plans or photos, the proposed Norse ruin on Iluillup Qeqertaa must, for now, be regarded as highly doubtful, and it is alarming that only Andersen (1982 has reported this, apparently rather substantial, feature. If indeed a Norse feature, the size and build of the ruin would imply functionality as a seasonally occupied hunting station or a marine waystation, which could explain 


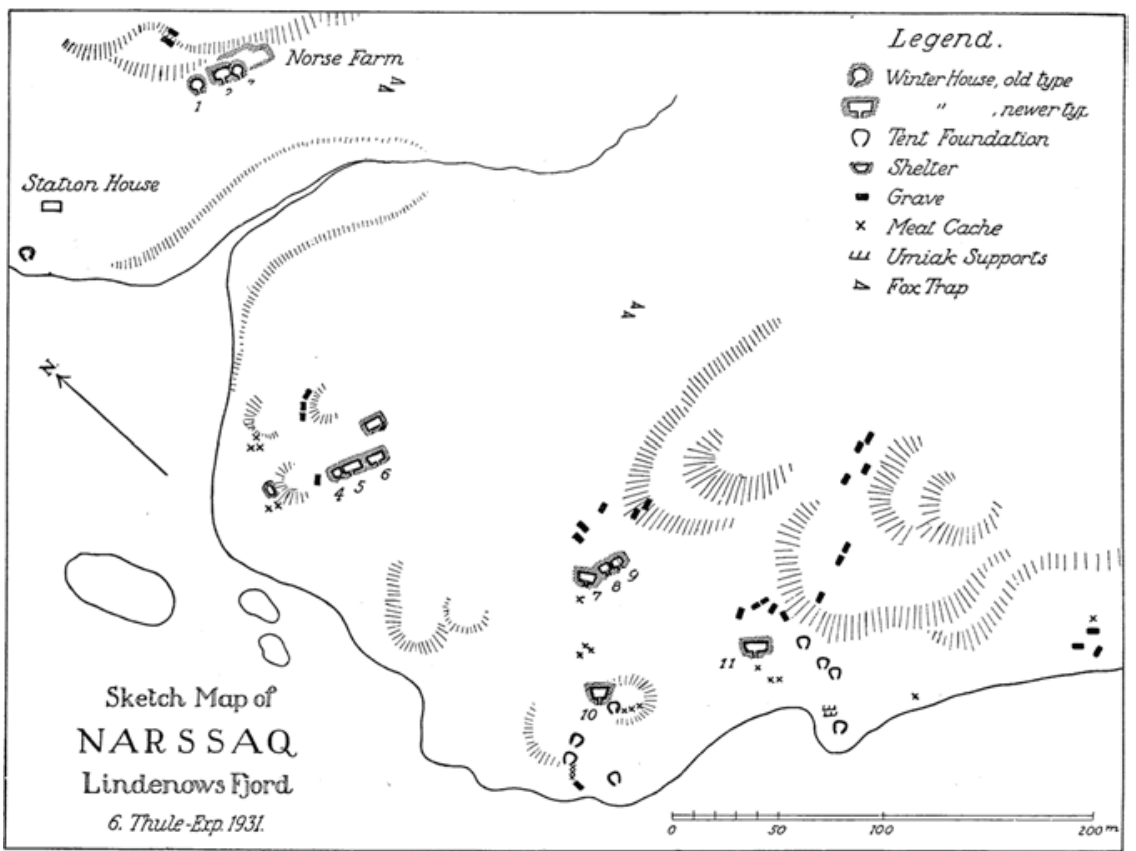

Figure 21. Site sketch overview plan of the Narsaq plain with Norse site NKAH 1506 (Ø117)_ “Rolf's ruin"-and Thule culture site NKAH 1941 (after Mathiassen 1936:Fig. 1).

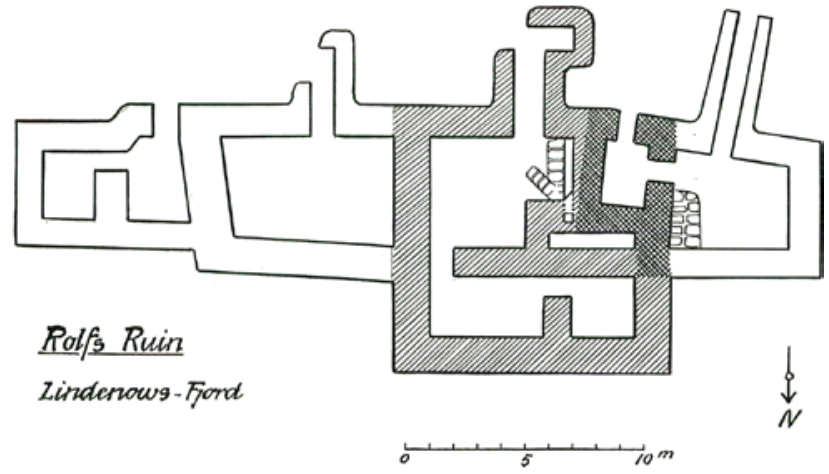

Figure 22. Previously unpublished sketch survey plan of the main Norse ruin at NKAH 1506 (Ø117) based on an original, coarser sketch in Poul Nørlund's field diary (1932:23), both found in the archives of the National Museum of Denmark.

the site's setting in the outermost fjord at the edge of the open ocean and drift-ice floe.

NKAH 2046, Avaqqat, Avaqqat Kangerluat, $61^{\circ}$ Latitude:

The site includes one suggested Norse ruin located at the head of an inlet on the northern side of the Karrat promontory by the mouth of Avaqqat
Kangerluat (Fig. 1A), where good natural sheltered harbors and tent sites are mentioned (Holm 1889:174). However, the only existing record on the Norse ruin is from Andersen (1982). A later attempt to relocate the ruin did not manage to reach the site (Gulløv 1999).

The suggested Norse ruin is described as a "very old feature" measuring $7 \times 5 \mathrm{~m}$ (Table 2), clearly rectangular of shape, and built of large stones, with one long side somewhat collapsed. Intensive surface search produced no artifacts (Andersen 1982). Unfortunately, no plan of the site has been published, but a photograph from Andersen's (1982:6) report shows a grassy surface with a large heap of collapsed medium-sized stone surrounding a central feature of somewhat larger stones, some of which are obviously lying in courses.

While NKAH 2046's possible Norse ruin certainly does not look to be of Thule culture or later Inuit origin, there is a chance that it could be the remnants of a later historical European building: a canon was found on a site (NKAH 3320) on the southern side of the Karrat headland, probably left behind by a marooned 18th-century whaling crew (Graah 1832:77). However, if the ruin is Norse, the large amount of collapsed medium-sized stones suggests that it was not a cold-period habitation building but perhaps a small marine-hunting station or waystation. 


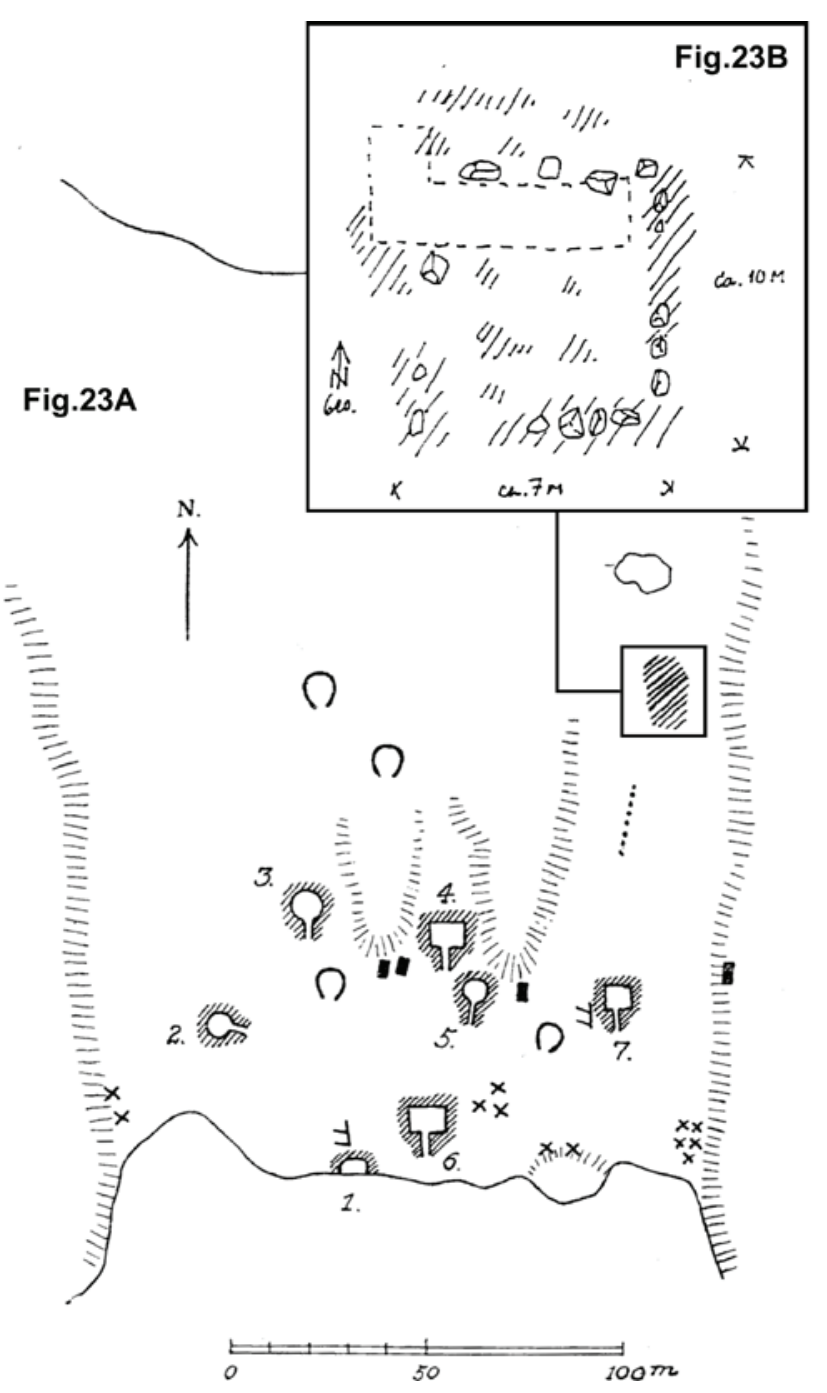

Figure 23. A. Site sketch overview plan of NKAH 3358, Timmiarmiut, showing the Thule culture settlement features and an indication of the possible Norse ruin test excavated by Nørlund in 1932 (after Mathiassen 1936:Fig. 13). B. Detailed sketch plan of the possible Norse ruin with indication of individual stones and the trench excavated by Nørlund in 1932 (after Gulløv 1999:23).

NKAH 3358, Timmiarmiut, Timmiarmiit Kangertivat, $62^{\circ}$ Latitude:

The site includes one possible Norse ruin placed near some Thule culture and later Inuit features on a narrow isthmus below a steep bird cliff about one third into the Timmiarmiit Kangertivat (fjord) (Fig. 1A and 23). Prior site descriptions are by Graah (1832), Gulløv (1999), Holm (1889), Mathiassen (1932, 1936), and Nørlund 1932a).

The ruin is described as a low, uneven, and grass-covered hummock, measuring $~ 10.0-$ $11.5 \times 9.0 \mathrm{~m}$ (Table 2), littered with largish stones of varied size and shape. Some of these stones appear to form lines along the edges of the hummock (Fig. 23B), which was disturbed by a cache in the northeastern corner (Mathiassen 1932). Unspecified test excavation led the latter archaeologist to interpret it as a natural feature, an opinion shared by Gulløv (1999).

However, Norse archaeologist Poul Nørlund had also carried out test excavation of the feature in 1932 and that same year wrote of the results in a letter to Knud Rasmussen:

I, therefore, settled with excavating a trench in the northern side of the ruin, where there were refuse layers. Among the refuse was lots of stone and turf lumps, which thus have been the building material (the stones were in part rather large). I found quite a bit of charcoal and especially-at a depth of $\sim 75 \mathrm{~cm}$-a great number of charred bones. . . . I also found a small sherd of a soapstone vessel (author's translation of Nørlund 1932a:2).

Nørlund's (1932b:30-35) field notes contain a similar brief description of the investigation, although he there adds that there was also some disturbance and activity by the later Thule occupants. Whether Norse or not, Nørlund's brief description rules out that the feature should be natural.

The Timmiarmiut region was historically an important maritime logistic nodal point because the environs of this fjord offered the first hospitable, vegetated, and ice-free lands after an almost $200 \mathrm{~km}$ stretch of rugged and glaciated coastline from Kangerlussuatsiaq (Lindenow Fjord) (Graah 1832; Holm 1889; Mathiassen 1936). The region also offered some of the best marine-hunting grounds on Greenland's east coast, which prior supported a fairly dense Inuit population. Large seabird colonies and steatite sources were also found there (Graah 1832). Based on this setting, and the description of the possible Norse ruin, the site appears a likely candidate for a second Norse specialized/provisional basecamp in East Greenland. Timmiarmiut was also one of the sites recurrently suggested when 19th-century European explorers asked local Inuit about the possible existence of Norse sites in East Greenland. ${ }^{2}$

\section{Discussion of the Archaeological Evidence on Norse Marine Shielings}

This survey of possible Norse marine shielings in Greenland is clearly hampered by the varied level of detail in site records, a lack of excavations, and the small number of sites. Reviewing the 17 sites examined here (Table 3), three can be dismissed as not Norse (NKAH 1107, 3080, and 3789), four sites are highly uncertain Norse (NKAH 2046, 3304, 


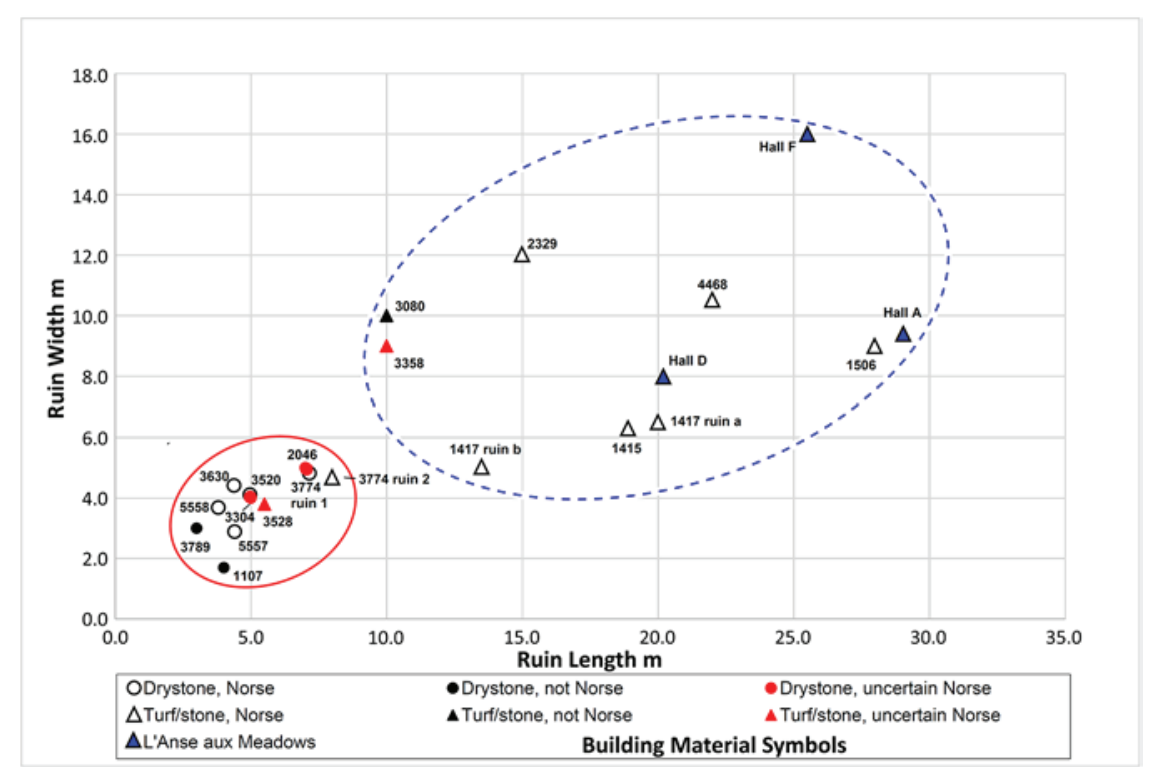

Figure 24. Plot of lengths, widths, and building materials (see Table 2) of the Norse ruins considered as possible marine shielings in Greenland, as well as three comparable features from L'Anse aux Meadows, Newfoundland. The two main clusters of dry-stone and turf/stone buildings are highlighted by red (solid) and blue (dashed) ellipses, respectively; other plot details are discussed in the text.

3358, and 3528), three sites appear to be shielings with a multipurpose, more-terrestrial orientation (NKAH 1415, 1417, and 2139), leaving eight sites that appear distinctly Norse marine shielings

(NKAH 1506, 3529, 3520, 3630, 3774, 4468, 5558, and 5557).

The few examples of verified Norse marine shielings is in itself a cause for concern, and several explanations must be considered:

1. That the extent and regularity of Norse hunting in the óbyggðir was less than implied by the medieval written and zooarchaeological evidence;

2. That Norse marine shielings have not been systematically searched for, or in the wrong places;

3. Third, when tentatively identified outside the settlement areas, potential Norse sites are submitted to more critical demands for verification;

4. They are hidden under later Thule culture features. The present author believes all but the first of these factors to be in play and that Norse marine shielings are underrepresented, especially within the settlement areas.

At the same time, however, considering the small Norse population, it should also be emphasized that the scale the marine hunting in the óbyggðir was probably never great. Most likely, no more than a handful of crews were ever working simultaneously, returning to the same few sites year after year.

\section{General Trends}

Figure 24 plots the dimensions of the 22 ruins considered here, as well as their main building material (Table 2), including three Norse dwellings at L'Anse aux Meadows, Newfoundland. There are two discernible clusters: first, a cluster of mostly dry-stone ruins of fairly uniform size; second, a more variable cluster of larger turf/stone buildings. Two non-Norse dry-stone ruins (NKAH 1107 and 3789, black dots in Fig. 24) plot as faint outliers to the confirmed Norse dry-stone cluster, whereas uncertain dry-stone ruins (red dots in Fig. 24) overlap, perhaps adding credibility to their interpretation as Norse? In the set of turf/ stone ruins, there are two outliers: NKAH 3528's uncertain Norse ruin and NKAH 3774's Norse Ruin 2 (red- and white-filled triangles in Fig. 24, respectively). Both are suggested as periodic marine-hunting stations, because of their relatively thin walls and only partly sheltered setting (Table 2 and 3). Otherwise, Fig. 24 mainly shows the greater dimensional variability the turf/stone ruins, probably reflecting their greater functional variability, also implied by their multiroom layouts (Table 2). 
Reviewing Table 2, there is a good correlation between ruin details and the functional classification scheme (Table 1): Type 1 or 2 turf or turf/stone buildings have slightly wider walls than Type 3 dry-stone buildings (i.e., reflecting the former's insulating properties). This correlation is also supported by building ground and wind-exposure settings, where all but one (NKAH 3528) Type 1 or 2 turf or turf/stone buildings occupy sheltered or partly sheltered, less heat draining soil surfaces (Table 2). For added heating, turf and turf/stone buildings are usually orientated to maximize sunlight exposure of one longwall (Roussell 1941).

In contrast, Type 3 dry-stone buildings are found on both soil and bedrock surfaces, and in sheltered to fully exposed settings, mirroring the previously described functional variation within the set. For instance, the two Type 3c dry-stone buildings (NKAH 3630 and 5558) sit on bedrock surfaces in fully wind-exposed terrain (Table 2) (i.e., for maximized ventilation and cooling), whereas the Type 3d dry-stone buildings occupy more-sheltered settings, on soil or bedrock surfaces (i.e., ventilation was not a primary factor in their placing).

Observed irregularities in the set can owe equally to flaws in the classification scheme (Table 1), the inclusion of non-Norse buildings, and differences in the archaeological surface recording of often dilapidated Norse ruins. One of the most noticeable outliers on several observation criteria is NKAH 3528's uncertain Norse ruin, which is the only turf or turf/stone building with combined small dimensions, thin walls, and bedrock building ground (Table 2), adding to the already-noted concern that it could be a later historical feature. NKAH 1415's Ruin 1 stands out from the other turf and stone/turf buildings with its north-south orientation, but this may have more to do with the unusual shaded site setting (Table 3 ), which points strongly to the periodic or provisional character of the site.

Table 3 summarizes the key site observation parameters for the 17 Norse sites investigated, as well as their suggested functional interpretation: all sites are characterized by absence of homefields, middens, or other substantial cultural deposits; sites facilitating human cold-period habitation occupied a sheltered and sunny settings with good to average landing conditions; and sites that were more periodically occupied, NKAH 3774 and problematic NKAH 3528, as well as shaded NKAH 1415, were apparently less oriented for maximum sunlight exposure. The only site to appear truly anomalous with poor landing conditions is NKAH's 1107, one of the sites dismissed as being Norse.

\section{Norse Marine Shieling Types}

Combining ruin and site selection criteria with geographical setting and resource access, at least four types of Norse marine shielings can be tentatively identified:

Marine waystations (NKAH 3630, 5558, and perhaps 3304) are interpreted as food (and equipment?) stores placed at advantageous and visible points along main Norse sea routes, functioning simultaneously as maritime nodal points, landmarks, depots, and safe harbors. With Type 3c dry-stone walls, bedrock building grounds, and wind-exposed settings (Table 2 and 3 ), the associated buildings must have served to keep ventilated, dry, and cool whatever was stockpiled inside (i.e., long-term storage and curing of foodstuffs or other organic materials). While these organic materials could have been walrus and narwhal tusks as suggested by some authors (Appelt and Gulløv 2009; Meldgaard 1995), it seems somewhat questionable that Norse hunters would have abandoned their valued bounty for any length of time considering the possible presence of competing crews and, from at least the 13th century, numerous Thule culture groups (Appelt and Gulløv 2009). At any rate, the two convincing Norse sites are topographically positioned in such a way that ships taking a near-coast, inner-skerries route along the coast would inevitably pass by them.

To the author's knowledge, there are no direct North Atlantic parallels to such marine waystations, but they functionally compare to maritime transit systems with fixed "landing places" known from Viking Age and Medieval Scandinavia, which also served to increase expedient and safe sea travels and trade (e.g., Jørgensen 2009; Sindbæk 2009; Wickler 2016b). Strategic laying out of food depots, although after a less substantial and fixed system, also made possible many early European expeditions in the Arctic (e.g., Graah 1832; Holm 1889). However, for Norse marine waystations to work effectively, they would have to be positioned in a chain along the coasts, which cannot be confirmed with only two or three presently identified sites. Given the distinct geographic and topographic setting of NKAH 3630 and 5558, they do indicate where new marine waystations could be discovered.

Landing sites (NKAH 3520 and 5557) are interpreted as stores for marine tools and equipment (e.g., nets, rope, oars, sails, tar, and the like) placed where landing boats were convenient and often as satellites to farmsteads that did have easy access to open fjord waters (Table 3). The two identified examples both present buildings with thick 
Type 3d dry-stone walls (Table 1 and 2) and both are sited on drained surface very close to the fjord. Since ventilation was clearly not a primary concern (Table 2), they were rather buildings meant to keep tools and equipment dry and secure, their heavy construction and wall infilling possibly being a measure to counter their exposure to storms and sea spray.

Marine-hunting stations (NKAH 3774 and perhaps NKAH 2046 and 3528) are interpreted as such because they present habitation buildings surrounded by exceedingly poor pastureland but good access to marine resources. Judging from their small dimensions, such hunting stations are likely to have served a single farm, at most a couple, on a periodic basis, including cold periods. The only confirmed Norse example, NKAH 3774, includes both a habitation building and a marine tool-and-equipment store, while the other two consist of single habitation buildings. The closest North Atlantic parallel to such hunting stations are probably houses on small fishing stations- or camps found in both Iceland and Norway, where farmers would stay seasonally to fish, and perhaps hunt whales (Amundsen et al. 2005; Edvardsson 2005; Edvardsson 2010; Wickler 2016a).

Specialized/provisional basecamps (NKAH 1415, 1417, 1506, 2139, 4468, and perhaps 2329 and 3358) are designated so because they could be either fixed basecamps to where groups of Norse travelers or hunters returned on seasonal basis, or reflect single or short-lived events (e.g., failed attempts to establish farmsteads or buildings for overwintering marooned crews). They stand out from the marine-hunting stations by presenting more substantial and insulated buildings (Table 2; Fig. 24). For obvious reasons, specialized/provisional basecamps are mainly found in the óbyggðir and, in contrast to the other marine shielings, are located somewhat into the fjords, perhaps to access a range of both marine and terrestrial resources. This situation, of course, makes any functional distinction between marine or terrestrial basecamp functions problematic, but also largely inconsequential, as they could serve both as geographically fixed seasonal or provisional, including winter-period, safe havens for Norse travelers or hunters. However, NKAH 4468 and the possible Norse ruin at NKAH 3358 do seem to have a clear marine orientation (i.e., may have served as marine-hunting camps for sizable crews).

In terms of the interpretation and characteristics of the specialized/provisional basecamps, the L'Anse aux Meadows site (Fig. 25), Newfoundland, provides a pertinent archaeological parallel (Ingstad 1977; Wallace 1991, 2003, 2006). Birgitta Wallace (2003:11) has convincingly argued that the site was a Norse "highly specialized, non-farming settlement," more specifically "a specialized [winter] basecamp for further exploration and a gateway to resources" (Wallace 2009:118) in North America, and that the site could be synonymous with the Leifsbuðir of the Sagas.

This premise effectively makes L'Anse aux Meadows the most thoroughly excavated, dated (late 10-11th centuries AD), and inventoried archaeological example of a Greenland Norse shieling within the proposed category of specialized/ provisional basecamps. Summarizing key points made by Wallace $(2003,2006,2009)$, such specialized (winter) camps may be characterized by: a) an atypical, and isolated, geographic setting; b) thickwalled, turf-insulated, multiroom living quarters for groups of people (Fig. 25, Hall A, D, and F); c) absence of livestock and buildings, and only few specialized outbuildings (Fig. 25, Houses B, C, E, and G and Furnace Hut); d) deposition of few personal or household items; and e) very slight cultural, floor, and midden deposits-an observation also noted by Svensson (2015:295)—suggestive of short occupation period and/or specialized onsite activities. These key characteristics appear to apply to all the examples of specialized/provisional basecamps presented above, and the similarity between NKAH 4468 and Hall F at L'Anse aux Meadows is striking (Fig. 19 and 25).

Whether or not L'Anse aux Meadows is synonymous with Leifsbuðir of the medieval written record, it raises the possibility that the Old Norse "buðir" (booths) place-names could, in fact, refer to such types of specialized/provisional basecamps. Other examples of buðir in Greenland have mainly been discussed in the context "thing" (assembly) sites (e.g., Bruun 1895; Clemmensen 1911; Gulløv 2008a; Nørlund and Stenberger 1934) as known both historically and archaeologically from Iceland (e.g., Byock 2002; Harrison et al. 2008; Mehler 2015; Vésteinsson 2013). However, based on this analysis, buðir should-as suggested elsewhere-perhaps rather signify any type of temporary or seasonal "lodging for travelers, seafarers, fishermen, or hunters" (Magnusen 1827b:326) in the context of medieval Norse Greenland.

To conclude, the aim of this study is clearly not to provide any definite model for the development, organization, and practices of marine-resource use in Norse Greenland, but rather to direct attention towards understudied archaeological aspects of the marine economy and how these aspects may be approached in terms of new interpretational frameworks. Regrettably, the scope of the article does not allow for any lengthy consideration of the study's wider implications, 


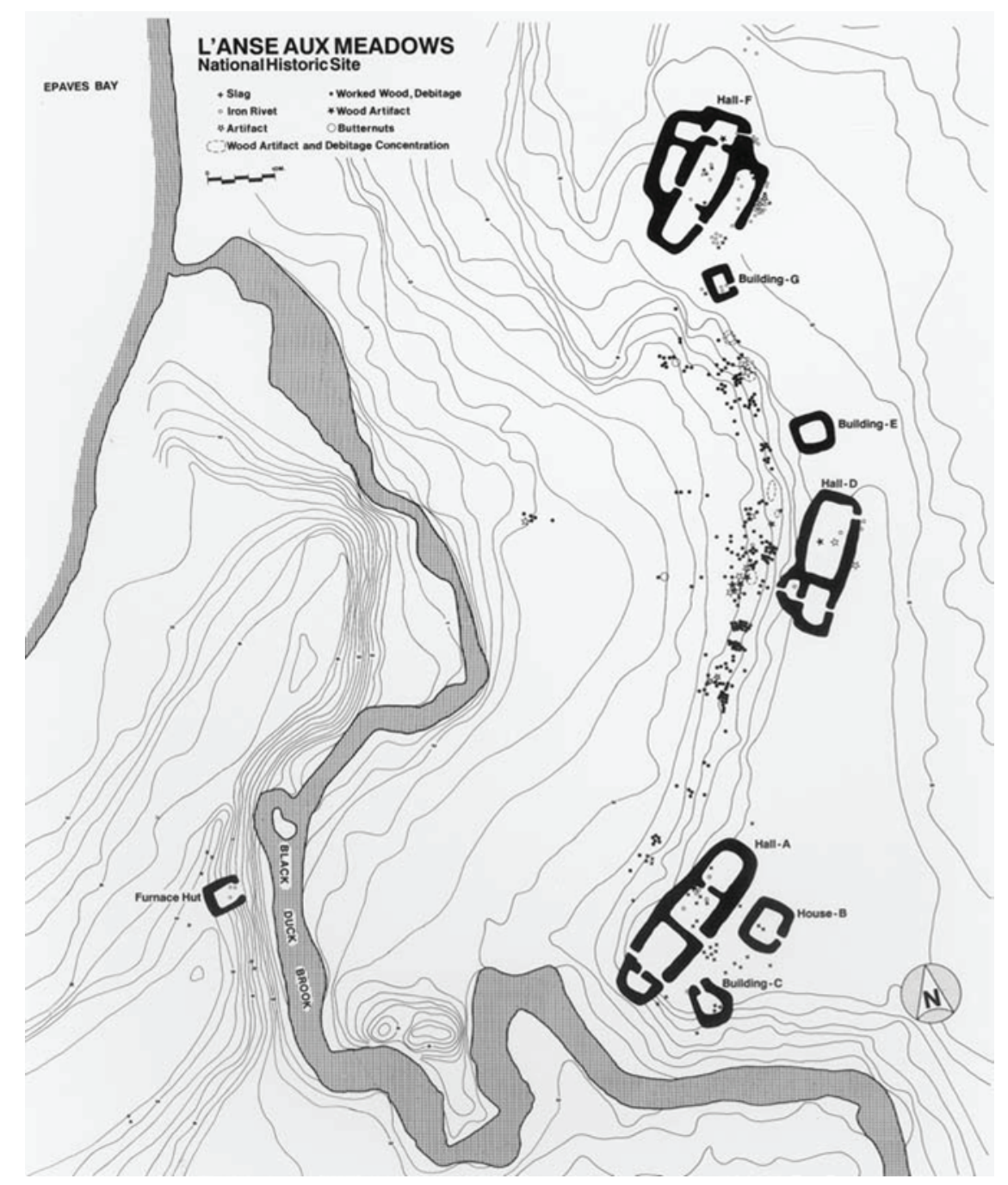

Figure 25. Site plan of the Norse settlement at L'Anse aux Meadows (after Wallace 2003:Fig. 2). Note the similarity of Hall F with NKAH 4468 (see Fig. 19).

for instance: What was the scale and extent of marine-resource use and hunting voyages? How did it align with the tasks and organization of the agropastoral economy? How did it affect the gendered labor division and scheduling? Neither is it possible here to provide a lengthy or formal comparison with marine sites and features in other North Atlantic areas, not only because of the sheer volume of evidence to consider, but also because the archaeological evidence from the latter regions is most often framed and interpreted within historical and ethnographic - and in many places still on-going-traditions and terminologies that simply lack from Norse Greenland. However, the concept of "marine shielings" could perhaps serve as an overlying archaeological category to more broadly discuss and compare understudied marine sites with different functions and designations, but similar importance and wider implications, across the North Atlantic.

\section{Conclusion}

Research of the last 40 years has demonstrated beyond doubt the great importance of marine resources in both the subsistence and trade economy of the medieval Norse that settled in Greenland from ca. AD 980-1450. A succinct review of medieval written evidence implies that Norse marine-resource exploitation in both North and East Greenland was frequent; undertaken by specialized crews that were organized and sponsored by wealthy, boat-owning elite farmers; to provide both cash crops and subsistence resources for the settlement areas; and logistically supported by specialized sites and buildings outside the main 
settlement areas and near the distant hunting grounds.

While the available evidence thus points to the existence of sites and features associated with marine-resource exploitation, little related archaeological evidence has been identified, and neither have systematic investigations been many. The present study is an attempt to improve this situation. Introducing a systematic interpretational framework for functional identification of Norse building surface remains and applying it to 17 suggested or confirmed Norse sites with an atypical or isolated geographical setting, evidence of at least four different types of marine shielings can be tentatively suggested:

- Marine waystations: served as geographically fixed food and equipment depots and stopovers along near-coast sea routes between the settlement areas and distant hunting grounds.

- Hunting stations: specialized satellite sites situated to improve access to marine-mammal wildlife to farmsteads inside and outside the Norse settlement areas.

- Landing sites: worked as marine-equipment stores offering advantageous boat landing to inland farmsteads or those with poor access to open fjord waters.

- Specialized/provisional basecamps: provided fixed, temporary quarters and havens for small groups of travelers, seafarers, or hunters, either on a regular seasonal basis or during critical events of marooning, being stopped by adverse environmental conditions. It is furthermore suggested that the specialized/provisional sites are the archaeological equivalent of the buðir (booths) that feature in the medieval written record on Norse Greenland.

While admittedly the presented sample of Norse sites is small and incomplete, and the interpretations of these sites are significantly hampered by lacking excavations and dates, the study suggests that Norse marine shielings are heavily underrepresented and attempts to offer some guidelines as to how to identify and categorize new marine shielings among existing sites, as well possibly where new similar sites could be located in the future.

Acknowledgments. The Danish Council for Independent Research is thanked for financing the postdoctoral Winter is Coming Project (WiCP) and the National Science Foundation for financing the collaborating Comparative Ecodynamics in the North Atlantic Project (CIE). The author wishes to thank The National Museum of Denmark and the Greenland National Museum \& Archives for housing the project and opening their archives, as well as the North Atlantic Biocultural Organization (NABO) for providing the academic network and support that has sustained and enriched the projects. Personal thanks are due to Jette Arneborg, Tom McGovern, Ian Simpson, Konrad Smiarowski, Michael Nielsen, and Cameron Turley, without the aid of whom the project and field campaigns would have been impossible. Also, thanks are given to Hans Lange, Mikkel Myrup, David Qaavigaq, Torben Diklev, Hans Kapel, Martin Appelt, and Hans Christian Gulløv for providing additional information and documentation on sites, and Orri Vésteinsson for translating passages from Björn Jónsson’s Grænlandsannáll.

\section{Endnotes}

1. The translation to English of the presented passages from Björn Jónsson's Grænlandsannáll was carried out by Prof. Orri Vésteinsson, University of Iceland, on May 4, 2018, at the personal request of the author.

2. The Norse archives of the National Museum of Denmark, Dept. of Middle Ages, Renaissance and Numismatics contain a folder with various early and largely unnamed accounts of possible Norse sites in East Greenland.

\section{References Cited}

Albrethsen, Svend Erik

1971 Nationalmuseets Nordbo-undersøgelser 1971 (unpublished report in the archives of the National Museum of Denmark, jr.nr. 33-349). Copenhagen: Nationalmuseet.

1982 Træk af den norrøne gårds udvikling på Grønland. In Vestnordisk byggeskikk gjennom to tusen år: Tradisjon og forandring fra romertid til det 19. årh. B. Myhre, B. Stoklund, and P. Gjærder, eds. Pp. 269-287, vol. AmS-Skrifter 7. Stavanger: Arkeologisk museum i Stavanger.

Albrethsen, Svend Erik, and Jette Arneborg

2004 Norse Ruins of the Southern Paamiut and Ivittuut Region. Volume 13. Copenhagen: SILA-The Greenland Research Centre at the National Museum of Denmark and the Danish Polar Center.

Albrethsen, Svend Erik, et al.

1990 Paamiut 1989. Registrering af kulturhistoriske anlæg i den sydlige del af Paamiut kommune samt i Ivittuut kommune. I. (unpublished report in the archives of Greenland National Museum and Archives, jr. nr. 33-163). Paamiut: Paamiut Museum.

Albrethsen, Svend Erik, and Christian Keller 1986 The Use of Saeter in Medieval Norse Farming in Greenland. Arctic Anthropology 23(1-2): 91-107. 
Albrethsen, Svend Erik, and Guðmundur Ólafsson 1998 A Viking Age Hall. In Man, Culture and Environment in Ancient Greenland: Report on a research programme. Jette Arneborg and Hans C. Gulløv, eds. Pp. 19-30. Viborg: Danish Polar Center and the Danish National Museum.

Amundsen, Colin, Sophia Perdikaris, Thomas H. McGovern, Yekaterina Krivogorskaya, Matthew Brown, Konrad Smiarowski, Shaye Storm, Salena Modugno, Malgorzata Frik, and Monica Koczela

2005 Fishing Booths and Fishing Strategies in Medieval Iceland: An Archaeofauna from the of Akurvík, North-West Iceland. Environmental Archaeology 10(2):127-142.

Andersen, John

1982 Vikingeekspedition 1982. Angmassilik-Nanortalik. Midlertidig rapport (unpublished report in the archives of Greenland National Museum and Archives, jr. nr. 33-037). Lyngby: John Andersen.

2006 Grønland. På oplevelse i Kajak (2. udg.). Copenhagen: Gyldendal.

Anderson, Rasmus B. ed

1906 The Flatey Book and Recently Discovered Vatican Manuscripts concerning America as Early as the Tenth Century. London: Norræna Society.

Appelt, Martin, and Hans Christian Gulløv

2009 Tunit, Norsemen, and Inuit in Thirteenth-Century Northwest Greenland - Dorset between the Devil and the Deep Sea. In The Northern World, AD 900-1400. Herbert Maschner, Owen Mason, and Robert McGhee, eds. Pp. 300-320. Salt Lake City: University of Utah Press.

Appelt, Martin, Hans Christian Gulløv, and Hans Kapel 1998 The Gateway to Greenland. Report on the Field Season 1996. In Man, Culture and Environment in Ancient Greenland. Report on a Research Programme. Jette Arneborg and Hans C. Gulløv, eds. Pp. 136-153. Copenhagen: Danish National Museum/Dansk Polar Center.

Arge, Símun V., Guðrún Sveinbjarnardóttir, Kevin J. Edwards, and Paul C. Buckland

2005 Viking and Medieval Settlement in the Faroes: People, Place and Environment. Human Ecology 33(5):597-620.

Arneborg, Jette

1998 The High Arctic "Utmark" of the Norse Greenlanders: The Norse Greenlanders' Use of High Arctic Resources. In Outland Use in Preindustrial Europe. Hans Andersson, Lars Ersgård, and Eva Svensson, eds. Pp. 156-167. Lund Studies in Medieval Archaeology, Vol. 20. Lund: Institute of Archeology, Lund University.

2004 Det Europæiske Landnam - Nordboerne i Grønland. In Grønlands forhistorie. Hans C. Gulløv, ed. Pp. 219-278. Copenhagen: Nordisk Forlag.
Arneborg, Jette, Jan Heinemeier, and Niels Lynnerup 2008 ». . . Husk at folk lever af flere ting end bare af brød «: De norrøne grønlænderes kost. Nationalmuseets Arbejdsmark 2008:149-160.

Arneborg, Jette, Niels Lynnerup, and Jan Heinemeier 2012a Human Diet and Subsistence Patterns in Norse Greenland AD c. 980-AD c. 1450: Archaeological Interpretations. Greenland Isotope Project: Diet in Norse Greenland AD 1000-AD 1450Journal of the North Atlantic. Special Volume 3: 119-133.

2012b Norse Greenland Dietary Economy ca. AD 980ca. AD 1450: Introduction. Greenland Isotope Project: Diet in Norse Greenland AD 1000AD 1450-Journal of the North Atlantic. Special Volume 3:1-39.

Bak, Ove

1971 Eskimoruiner registreret af Ove Bak (unpublished report in the archives of the National $\mathrm{Mu}-$ seum of Denmark, jr. nr. 33001_5). Sydprøven: Ove Bak.

1972 Nordboer. Besigtigelser 1968-71. Skitser og beskrivelser (unpublished field report in the archives of the Greenland National Museum \& Archives, jr. nr. 33-158). Sydprøven: Ove Bak.

Baug, Irene

2015 Actors in Quarrying. Production and Distribution of Quernstones and Bakestones during the Viking Age and the Middle Ages. In Everyday Products in the Middle Ages. Crafts, Consumptions and the Individual in Northern Europe c. AD 800-1600. Gitte Hansen, Steven P. Ashby, and Irene Baug, eds. Pp. 229-250. Oxford: Oxbow Books.

Bendixen, Ole

1929 Ekspeditionen til Cap Farvel Egnen. Geografisk Tidsskrift 32:160-179.

Berglund, Joel

1973 På den yderste nøgne Ø. SKALK 1973(4):11-12.

Berson, Bruno

2002 A Contribution to the Study of the Medieval Icelandic Farm: The Byres. Archaeologia Islandica $2: 37-64$

Bjørgmose, Rasmus

1967 Stensnæs—den glemte kirke. Odense: Nordisk litteratur folag.

Blehr, Otto

2012 Medieval Reindeer Drives at Sumtangen, Hardangervidda: Two Interpretations. Fornvännen 107(2):115-122.

Bolender, Douglas J., John M. Steinberg, and Brian N. Damiata

2011 Farmstead Relocation at the End of the Viking Age: Results of the Skagafjörður Archaeological Settlement Survey. Archaeologia Islandica 9:77-101. 
Born, Erik W., and Jens Böcher

2001 The Ecology of Greenland. D. Eiby-Jacobsen, translator. Nuuk: Greenland Ministry of Environment and Natural Resources.

Born, Erik W., Mads P. Heide-Jørgensen, and Rolph A. Davis

1994 The Atlantic Walrus (Odobenus rosmarus rosmarus) in West Greenland. Meddelelser om Grønland, Bioscience 40:1-33.

Brodbeck, Jakob

1882 Nach Osten: Untersuchungsfahrt nach der Ostküste Grönlands vom 2. bis 12. August 1881. Niesky: Missionsdepartement der Brüdergemeine.

Bruun, Daniel

1895 Arkæologiske Undersøgelser i Julianehaabs Distrikt. Meddelelser om Grønland 16:173-461.

1897 Fortidsminder og Nutidshjem paa Island. Orienterende undersøgelser foretagne i 1896. Volume Nordboernes Kulturliv i Fortid og Nutid. I. Island. Copenhagen: Nordisk Forlag.

1918 Oversigt over Nordboruiner i Godthaab- og Frederikshaab-Distrikter. Meddelelser om Grønland LVI:57-147.

1928a Fortidsminder og Nutidshjem paa Island. Copenhagen: Nordisk Forlag.

1928b Old Norse Farms in the Eastern and Western Settlements. In Greenland, Volume II: The Past and Present Population of Greenland. Martin Vahl, ed. Pp. 363-415. Copenhagen-London: Commission for the Direction of the Geological and Geographical Investigations in Greenland.

Bugge, Alexander

1914 Norges Kongesagaer-1914-utgaven. Kristiania: I. M. Stenersens Forlag.

Byock, Jesse

2002 The Icelandic Althing: Dawn of Parliamentary Democracy. In Heritage and Identity: Shaping the Nations of the North. J. Magnus Fladmark, ed. Pp. 1-18. Donhead St. Mary, Shaftesbury: The Heyerdahl Institute and Robert Gordon University.

Carrer, Francesco, André Carlo Colonese, Alexandre Lucquin, Eduardo Petersen Guedes, Anu Thompson, Kevin Walsh, Thomas Reitmaier, and Oliver E. Craig 2016 Chemical Analysis of Pottery Demonstrates Prehistoric Origin for High-Altitude Alpine Dairying. PLoS ONE 11(4):e0151442.

Cheape, Hugh

1996 Shielings in the Highlands and Islands of Scotland: Prehistory to the Present. Folk Life 35(1):7-24.

Church, M. J., A. J. Dugmore, K. A. Mairs, A. R. Millard, G. T. Cook, G. Sveinbjarnardttir, P. A. Ascough, K. H. Roucoux.

2016 Charcoal Production During the Norse and Early Medieval Periods in Eyjafjallahreppur, Southern Iceland. Radiocarbon 49(2):659-672.
Clemmensen, Mogens

1911 Kirkeruiner fra Nordbotiden i Julianehaab Distrikt. Meddelelser om Grønland 47:283-358.

Dietz, Rune, Mads Peter Heide-Jørgensen, Erik W. Born, and Christian M. Glahder

1994 Occurence of Narwhals (Monodon monoceros) and White Whales (Delphinapterus leucas) in East Greenland. Meddelelser om Grønland, Bioscience 39:69-86.

Dugmore, Andrew J., Christian Keller, Thomas H. McGovern, Andrew F. Casely, Konrad Smiarowski 2009 Norse Greenland Settlement and Limits to Adaptation. In Adapting to Climate Change: Thresholds, Values, Governance. W. Neil Adger, Irene Lorenzoni, and Karen L. O’Brien, eds. Pp. 96-113. Cambridge: Cambridge University Press.

Dugmore, Andrew J., Christian Keller, and Thomas H. McGovern

2007 Norse Greenland Settlement: Reflections on Climate Change, Trade, and the Contrasting Fates of Human Settlements in the North Atlantic Islands. Arctic Anthropology 44(1):12-36.

Edvardsson, Ragnar

2005 Commercial and Subsistence Fishing in Vestfirðir: A Study in the Role of Fishing in the Icelandic Medieval Economy. Archaeologia Islandica 4:51-67.

2010 The Role of Marine Resources in the Medieval Economy of Vestfirðir, Iceland. Ph.D. dissertation, Department of Anthropology, The City of University of New York, New York.

Egede, Paul

1740 Continuation af Relationerne betreffende den grønlandske Missions Tilstand og Beskaffenhed. Forfattet i Form af en Journal fra Anno 17341740. Copenhagen: Johan Cristoph Groth.

Enghoff, Inge Bødker

2003 Hunting, Fishing and Animal Husbandry at the Farm Beneath the Sand, Western Greenland. Meddelelser om Grønland, Man \& Society 28: 3-104.

Forbes, Bruce C.

2015 Arctic Vegetation Cover: Patterns, Processes and Expected Change. In The New Arctic. Birgitta Evengård, Joan Nymand Larsen, and Øyvind Paasche, eds. Pp. 117-132. Cham: Springer International Publishing.

Foster, Ryan

2018 Norse Shielings in Scotland: An Interdisciplinary Study of Setr/Sætr and Ergi-names. Ph.D. dissertation, University of Edinburgh, Edinburgh.

Frei, Karin M., Ashley N. Coutu, Konrad Smiarowski, Ramona Harrison, Christian K. Madsen, Jette Arneborg, Robert Frei, Gardar Guðmundsson, Søren M. Sindbæk, James Woollett, Steven Hartman, Megan Hicks, and Thomas H. McGovern 
2015 Was it for Walrus? Viking Age Settlement and Medieval Walrus Ivory Trade in Iceland and Greenland. World Archaeology 47(3):439-466.

Gad, Finn

1965 Sjældent farer mænd did. Tidsskriftet Grønland 3:81-91.

Gestsson, Gísli

1986 Kúabót í Álftaveri I. Árbók hins Íslenzka Fornleifafélags 1986:11-38.

Giesecke, Karl Ludwig

1825 On the Norwegian Settlements on the Eastern Coast of Greenland or Osterbygd, and Their Situation. The Transactions of the Royal Irish Academy XIV:47-57.

1910 Mineralogisches Reisejournal über Grönland. Meddelelser om Grønland 35:1-478.

Griffiths, David, and Jane Harrison

2011 Settlement under the Sand: New Viking Discoveries in Orkney. Current Archaeology 253:12-19.

Grove, Jonathan

2009 The Place of Greenland in Medieval Icelandic Saga Narrative. Journal of the North Atlantic 2(sp2):30-51.

Graah, Wilhelm August

1832 Undersøgelses-Reise til Østkysten af Grønland. Copenhagen: D. Qvist, i det Christensenske Officin.

Guðmundsson, Gardar, and Hörður Ágústsson 2006 The Reconstructed Medieval Farm in Pjórsárdalur and the Development of the Icelandic Turf House (2nd ed). K. Kunz, translator. Reykjavík: National Museum of Iceland.

Guldager, Ole, Steffen Stummann Hansen, and Simon Gleie

2002 Medieval Farmsteads in Greenland: The Brattahlid Region 1999-2000. Copenhagen: Danish Polar Center.

Gulløv, Hans Christian

1983 Fortidsminder i Nuuk kommune-inuit-kulturens bopladser/Nuup kommuneani qangarnitsanik eqqaassuti. Nuuk: Kalaallit Nunaata katersugaasivia and National Museum of Denmark.

1997 Porten til Grønland. Arkæologiske undersøgelser i Thule 1996. Unpublished field report in the archives of the National Museum of Denmark, reg. 33291. Copenhagen: National Museum of Denmark.

1999 Berejsning og undersøgelser i Qaqortoq, Narsaq, Nanortalik og Ammassalik kommuner, sommeren 1999. Unpublished report in the archives of the National Museum of Denmark. Copenhagen: National Museum of Denmark.

2008a Booths from Early Norse Greenland_or tjaldat búðir from landnáma Greenland. In Símunarbók. Caroline Paulsen and Helgi Dahl Michelsen, eds. Pp. 90-105. Tórshavn: Fródskapur. 2008b The Nature of Contact between Native Greenlanders and Norse. Journal of the North Atlantic 1(2008):16-24.

2016 Inuit-European Interactions in Greenland. In The Oxford Handbook of the Prehistoric Arctic. T. Max Friesen and Owen Mason, eds. Pp. 1-20. Oxford: Oxford University Press.

Halldórsson, Ólafur

1978 Grænland í miðaldaritum. Reykjavík: Sögufélag.

Harrison, Ramona, Howell M. Roberts, and W. Paul Adderley

2008 Gásir in Eyjafjörđur: International Exchange and Local Economy in Medieval Iceland. Journal of the North Atlantic 1(1):99-119.

Heide-Jørgensen, K. L. Laidre, M. L. Burt, D. L. Borchers, T. A. Marques, R. G. Hansen, M. Rasmussen, and S. Fossette

2010 Abundance of Narwhals (Monodon monoceros) on the Hunting Grounds in Greenland. Journal of Mammalogy 91(5):1135-1151.

Helle, Knut

1982 Kongssete og kjøpstad: fra opphavet til 1536. Bergen: Universitetsforlaget.

Holm, Gustav

1889 Den østgrønlandske Expedition udført i Aarene 1883-85. Meddelelser om Grønland 9(1).

Ihmer, Lisbeth

2017 Peasants and Prayers: The Inscriptions of Norse Greenland. Copenhagen: National Museum of Denmark.

Ingstad, Anne Stine, ed.

1977 The Discovery of a Norse Settlement in North America: Excavation at L'Anse Aux Meadows, Newfoundland, 1961-1968. Oslo: Norwegian University Press.

Ingstad, Helge

1960 Landet under Polarstjernen. Copenhagen: Forlaget Fremad.

Isachsen, Gunnar, and Fridjov Isachsen

1932 Hvor langt mot nord kom de norrøne grønlendinger på sine fangstferder i ubygdene? Norsk Geografisk Tidsskrift Bind IV(Hefte 1-3):75-92.

Jensen, Jens Arnold Diderich

1879 Expeditionen til Syd-Grønland i 1878. Meddelelser om Grønland 1:17-76.

Jim, C. Y.

2017 An Archaeological and Historical Exploration of the Origins of Green Roofs. Urban Forestry \& Urban Greening 27:32-42.

Jones, Gwyn

1986 The North Atlantic Saga. Second edition. Oxford: Oxford University Press.

Jónsson, Finnur

1899 Grønlands gamle Topografi efter Kilderne. Østerbygden og Vesterbygden. Meddelelser om Grønland 20:265-329. 
1930 Det gamle Grønlands beskrivelse af Ívar Bárðarson. Copenhagen: Levin \& Munksgaard Forlag.

Jørgensen, Ulrik

2009 Viking-Age Sailing Routes of the Western Baltic Sea-A Matter of Safety. In Wulfstan's Voyage: The Baltic Sea Region in the Early Viking Age as Seen from Shipboard. Anton Englert and Athena Trakadas, eds. Pp. 135-144. Maritime Culture of the North, vol. 2. Roskilde: Roskilde Viking Ship Museum.

Keller, Christian

1990 Vikings in the West Atlantic: A Model of Norse Greenland Medieval Society. Acta Archaeologica 61(1990):127-141.

2010 Furs, Fish, and Ivory: Medieval Norsemen at the Arctic Fringe. Journal of the North Atlantic 3(1):1-23.

Krogh, Knud J.

1976 Om grønlands middelalderlige kirkebygninger. In Minjar og menntir. Afmælisrit helgað Kristjáni Eldjárn 6. Desember 1976. Bjarni Vilhjálmsson, Jónas Kristjánsson, and Pór Magnússon, eds. Pp. 294-310. Reykjavík: Bókaútgáfa Menningarsjóð.

1982 Bygdernes kirker. Kirkerne i de middelalderlige, norrøne grønlandske bygder. Tidsskriftet Grønland 1982(8):263-274.

Krogh, Knud J., Margrethe Berglund, and Joel Berlund 1980 Antikvariske arbejder i Narssak, Julianehåb og Nanortalik kommuner, Grønland 1980 (unpublished survey report in the archives at Greenland National Museum \& Archies, jr.nr. 198002). Copenhagen: Nationalmuset.

Kupiec, Patrycja, and Karen Milek

2014 Roles and Perceptions of Shielings and the Mediation of Gender Identities in Viking and Medieval Iceland. In Viking Worlds: Things, Spaces and Movement. Marianne Hem Eriksen, Unn Pederson, Bernt Rundberget, Irmelin Axelsen, and Heidi Lund Berg, eds. Havertown: Oxbow Books.

Larson, Laurence Marcellus

1917 The King's Mirror (Speculum Regale-Konungs Skuggsjá). Laurence M. Larson, transl. London: Oxford University Press.

Ledger, Paul M., Kevin J. Edwards, and Edward J. Schofield

2013 Shieling Activity in the Norse Eastern Settlement: Palaeoenvironment of the "Mountain Farm," Vatnahverfi, Greenland. The Holocene 23(6):810-822.

Ljungqvist, Frederik Charpentier

2005 The Significance of Remote Resource Regions for Norse Greenland. Scripta Islandica 56: 13-54.
Long, Antony J., Sarah A.Woodroff, Glenn A.Milne, Charlotte L.Bryant, Matthew J.R.Simpson, and Leanne M. Wake

2012 Relative Sea-Level Change in Greenland during the Last 700 Yrs and Ice Sheet Response to the Little Ice Age. Earth and Planetary Science Letters 315-316:76-85.

Lynnerup, Niels

1998 The Greenland Norse. A Biological-Anthropological Study. Meddelelser om Grønland, Man \& Society 24:3-149.

Madsen, Christian K.

2014a Norse Pastoral Farming and Settlement in the Vatnahverfi Peninsula, South Greenland. In Northern Worlds: Landscapes, Interactions and Dynamics: Research at the National Museum of Denmark. Proceedings of the Northern Worlds Conference Copenhagen 28-30 November 2012. Hans C. Gulløv, ed. Pp. 95-114. PNM-Publications from the National Museum, Studies in Archaeology \& History, vol. 22. Copenhagen: National Museum of Denmark.

2014b Pastoral Settlement, Farming, and Hierarchy in Norse Vatnahverfi, South Greenland. Ph.D. dissertation, Saxo-Institute, Faculty of Humanities, University of Copenhagen, Copenhagen.

Magnusen, Finn

1827a VIII. Efterretninger om en i Grønland funden Runesten, med dens Forklaring, forfattet af Prof. Rask, og nogle hertil hørende oplysninger ved Prof. Finn Magnusen. Antiquariske Annaler Fjerde Bind(Andet Hefte):309-342.

1827b X. Tillæg til Efterretningerne om den Grønlandske Runesten m.m. Antiquariske Annaler Fjerde Bind(Andet Hefte):367-378.

Mahler, Ditlev L.

2007 Sæteren ved Argisbrekka. Tórshavn: Fróðskapur.

Mathers, Derek

2009 A Fourteenth-Century Description of Greenland. In Saga Book Vol. XXXIII. Viking Society for Northern Research, University of College of London. Alison Finlay, Christina Lee, John McKinnell, and Carl Phelpstead, eds. Pp. 67-92. Exeter: Short Run Press Ltd.

Mathiassen, Therkel

1932 Arkæologisk Journal. Kysten Angmagssalik-Kap Farvel, 1932. Unpublished field journal in the archives of the National Museum of Denmark, jr.nr. 33-103. Copenhagen: National Museum of Denmark.

1936 The Former Eskimo Settlements on Frederik VI's Coast. Meddelelser om Grønland 109(2):3-55.

Mathiassen, Therkel, and Erik Holtved

1936 The Eskimo Archaeology of Julianehaab District. Meddelelser om Grønland 118(1):1-141. 
Matras, Anna Katrin

2005 The Viking Settlement “Niðri á Toft,” Kvívík, Faroe Islands-A Reanalysis. In Viking and Norse in the North Atlantic: Select Papers from the Proceedings of the Fourteenth Viking Congress, Tórshavn, 19-30 Juli 2001. Andras Mortensen and Simun V. Arge, eds. Pp. 99-108. Tórshavn: Føroya Fróðskaparfelag.

McCullough, Karen, and Peter Schledermann

2009 Mystery Cairns on Washington Irving Island. Polar Record 35(195):289-298.

McGovern, Thomas H.

1979 The Paleoeconomy of Norse Greenland: Adaptation and Extinction in a Tightly Bounded Ecosystem. Ph.D. dissertation, Columbia University, New York.

1985a Contributions to the Paleoeconomy of Norse Greenland. Acta Archaeologica 54:73-122.

1985b The Arctic Frontier of Norse Greenland. In The Archaeology of Frontiers and Boundaries. Stanton W. Green and Stephen M. Perlman, eds. Pp. 275-323. New York: Academic Press.

McGovern, Thomas H., Thomas Amorosi, Sophia Perdikaris, and James Woollett

1996 Vertebrate Zooarchaeology of Sandnes V51: Economic Change at a Chieftain's Farm in West Greenland. Arctic Anthropology 33(2): 94-121.

McGovern, Thomas H., and Richard H. Jordan 1982 Settlement and Land Use in the Inner Fjords of the Godthaab District, West Greenland. Arctic Anthropology 19(1):63-79.

Mehler, Natascha

2015 Pingvellir: A Place of Assembly and a Market? Journal of the North Atlantic Special Volume 8:69-81.

Meldgaard, Jørgen

1965 Nordboerne i Grønland: En Vikingebygds Historie. Copenhagen: Munksgaards Forlag.

1995 Eskimoer og Nordboer i det yderste Nord. Nationalmuseets Arbejdsmark. Olad Olsen, ed. Pp. 199-214. Copenhagen: Danish National Museum.

Mikkelsen, Naja, Antoon Kuijpers, and Jette Arneborg

2008 The Norse in Greenland and Late Holocene Sea-Level Change. Polar Record 44(228): $45-50$.

Møhl, Jeppe

1982 Ressourceudnyttelse fra norrøne og eskimoiske affaldslag belyst igennem knoglematerialet. Tidsskriftet Grønland 8-9:286-295.

Nansen, Fridtjof

1911 In Northern Mists: Arctic Explorations in Early Time, vol. 1. Arthur G. Chater, transl. London: Ballantine Press.
Nørlund, Poul

1921 Beskrivelse af ruingruppe Ø148, Serfa Iterdla (unpublished site record in the archives of the National Museum of Denmark). Copenhagen: National Museum of Denmark.

1932a Brev fra Nørlund til Knud Rasmussen, 1932, vedr. ruiner i Lindenow Fjorden og bag Skjoldungen. Unpublished letter in the archives at the National Museum of Denmark, jr.nr. 33-104. Copenhagen: National Museum of Denmark.

1932b Poul Nørlunds notesbog 1932 (Østerbygden) (unpublished field notes in the archives of the National Museum of Denmark). Copenhagen: National Museum of Denmark.

Nørlund, Poul, and Mårten Stenberger

1934 Brattahlid. Meddelelser om Grønland 88(1): 1-161.

Ogilvie, Astrid E. J.

1991 Climate Changes in Iceland A.D. c. 865 to 1598. Acta Archaeologica 61:233-251.

Ogilvie, Astrid E. J., James M. Woollett, Konrad Smiarowski, Jette Arneborg, Simon Troelstra, Antoon Kuijpers, Albina Pálsdóttir, and Thomas H. McGovern

2009 Seals and Sea Ice in Medieval Greenland. Journal of the North Atlantic 2(1):60-80.

Øye, Ingvild

2004 Agricultural Conditions and Rural Societies ca. 800-1350: An Introduction. In Norwegian Agricultural History. Reidar Almås and Brynjulv Gjerdåker, eds. Pp. 80-140. Trondheim: Tapir Academic.

2005 Farming and Farming Systems in Norse Societies of the North Atlantic. In Viking and Norse in the North Atlantic: Select Papers from the Proceedings of the Fourteenth Viking Congress, Tórshavn, 19-30 Juli 2001. Andras Mortensen and Simun V. Arge, eds. Pp. 359-370. Tórshavn: Føroya Fróðskaparfelag.

2013 Technology, Land Use and Transformations in Scandinavian Landscapes, c. 800-1300 AD. In Economic Archaeology: From Structure to Performance in European Archaeology. Tim Kerig and Andreas Zimmerman, eds. Pp. 295-309. Bonn: Dr. Rudolf Habelt GmbH.

Perdikaris, Sophia, and Thomas H. McGovern

2008 Codfish and Kings, Seals and Subsistence. In Human Impacts on Marine Environments: A Global Perspective. Torben C. Rick and Jon M. Erlandson, eds. Pp. 187-214. Oakland: University of California Press.

Petersen, Hans Christian

1979 Iagtagelser af "nordbospor" i Kangâtsiaq kommune. Unpublished report in the archives of Greenland National Museum \& Archives. Nuuk: Greenland National Museum \& Archives. 
Pingel, Christian

1832 Antiquariske Efterretninger. Grønland. Nordisk Tidsskrift for Oldkyndighed 1:221-225.

1833 Antiquariske Efterretninger. Grønland. Nordisk Tidsskrift for Oldkyndighed 1:313-343.

Porter, Claire, Paul Morin, Ian Howat, Myoung-Jon Noh, Brian Bates, Kenneth Peterman, Scott Keesey, Matthew Schlenk, Judith Gardiner, Karen Tomko, Michael Willis, Cole Kelleher, Michael Cloutier, Eric Husby, Steven Foga, Hitomi Nakamura, Melisa Platson, Michael Wethington Jr., Cathleen Williamson, Gregory Bauer, Jeremy Enos, Galen Arnold, William Kramer, Peter Becker, Abhijit Doshi, Cristelle D’Souza, Pat Cummens, Fabien Laurier, and Mikkel Bojesen

2018 ArcticDEM. https://doi.org/10.7910/DVN/ OHHUKH, Harvard Dataverse, V1.

Reinton, Lars

1961 Seterbruk i Norge III. Volume III. Oslo: Institut for sammenlignende Kulturforskning.

Roesdahl, Else

2005 Walrus Ivory-Demand, Supply, Workshops, and Greenland. In Viking and Norse in the North Atlantic: Select Papers from the Proceedings of the Fourteenth Viking Congress, Tórshavn, 19-30 Juli 2001. Andras Mortensen and Simun V. Arge, eds. Pp. 182-207. Tórshavn: Føroya Fróðskaparfelag.

Rosenkrantz, Alfred

1967a Bjørnefælden ved Nûgssuaq og nordboernes Eysunes i geologisk belysning. Tidsskriftet Grønland 12:377-484.

1967b Runestenen fra Kingigtorssuaq i geologisk belysning. Tidsskriftet Grønland 11: 349-362.

Roussell, Aage

1936 Sandnes and the Neighboring Farms. Meddelelser om Grønland 88(2):5-232.

1941 Farms and Churches in the Medieval Norse Settlements of Greenland. Meddelelser om Grønland 89:1-354.

Raahauge, Kristine, Martin Appelt, Hans Christian Gulløv, Hans Kapel, Cicilie Krouse, and Niels Algreen Møller

2002 Tidlig Thule kultur i Sydgrønland. Rapport om undersøgelserne i Nanortalik Kommune, sommeren 2001. Copenhagen: SILA-The National Museum of Denmark.

Schledermann, Peter

2000 Ellesmere: Vikings in the Far North. In Vikings: The North Atlantic Saga. William W. Fitzhugh and Elizabeth I. Ward, eds. Pp. 248-256. Washington, D.C.: Smithsonian Institution Press.

Seaver, Kirsten A.

1996 The Frozen Echo. Stanford: Stanford University Press.
Smiarowski, Konrad, Ramona Harrison, Seth

Brewington, Megan Hicks, Frank J. Feeley, Céline Dupont-Hébert, Brenda Prehal, George Hambrecht, James Woollett, and Thomas H. McGovern

2017 Zooarchaeology of the Scandinavian Settlements in Iceland and Greenland: Diverging Pathways. In The Oxford Handbook of Zooarchaeology. Umberto Albarella, Hannah Russ, Kim Vickers, and Sarah Viner-Daniels, eds. Pp. 147-163. Oxford: Oxford University Press.

Sindbæk, Søren M.

2009 Open Access, Nodal Points, and Central Places: Maritime Communication and Locational Principles for Coastal Sites in South Scandinavia, c. AD 400-1200. Estonian Journal of Archaeology 13(2):96-109.

Skre, Dagfinn

1996 Rural Settlements in Medieval Norway, AD 400-1400. Ruralia I:53-71.

Skrede, Marit Anita

2005 Shielings and Landscape in Western NorwayResearch traditions and recent trends. In Utmark: The Outfield as Industry and Ideology in the Iron Age and the Middle Age. Ingunn Holm and Sonja Innselset, eds. Pp. 31-41. Vol. 1 of UBAS (Universitetet i Bergen arkeologiske skrifter), International. Bergen: University of Bergen.

Small, Alan

1967 Excavations at Underhoull, Unst, Shetland. Proceedings of the Society of Antiquaries of Scotland 98(1964-1966):225-248.

Star, Bastiaan, James H. Barrett, Agata T. Gondek, and Sanne Boessenkool

2018 Ancient DNA Reveals the Chronology of Walrus Ivory Trade from Norse Greenland. Proceedings of the Royal Society B: Biological Sciences 285(1884). doi.org/10.1098/rspb.2018.0978.

Steenstrup, Knud Johannes Vogelius

1893 Beretning om Undersøgelsesrejserne i

Nord-Grønland i Aarene 1878-80. Meddelelser om Grønland 5:1-41.

Stummann Hansen, Steffen

2013 4. The Viking Age Structures. Acta Archaeologica 84(1):38-65.

Sutherland, Patricia D.

2000 The Norse and the Native North Americans. In Vikings: The North Atlantic Saga. William W. Fitzhugh and Elizabeth I. Ward, eds. Pp. 238248. Washington, D.C.: Smithsonian Institution Press.

Sveinbjarnardóttir, Gudrun

1991 Shieling in Iceland: An Archaeological and Historical Survey. Acta Archaeologica 61:73-96.

Svensson, Eva

2015 Upland Living. The Scandinavian Shielings and Their European Sisters. In Nordic Middle 
Ages-Artefacts, Landscapes and Society: Essays in Honor of Ingvild Öye on Her 70th Birthday. Irene Baug, Janicke Larsen, Sigrid Samset Mygland, eds. Pp. 289-300. University of Bergen Archaeological Series, vol. 8. Bergen: University of Bergen.

Thorhallesen, Egill

1776 Efterretning om Rudera eller Levninger af de gamle Nordmænds og Islænderes Bygninger paa Grønlands Vester-Side tillige med et Anhang om deres Undergang Sammesteds. Copenhagen: August Friderich Stein.

Thorsteinsson, Arne

1982 Færøske huskonstruktioner fra vikingetid til 1800-årene. In Vestnordisk byggeskikk gjennom to tusen år: Tradisjon og forandring fra romertid til det 19. årh. Bjørn Myhre, Bjarne Stoklund, and Per Gjærder, eds. Pp. 149-161, Vol. AmSSkrifter 7. Stavanger: Arkeologisk Museum i Stavanger.

van Hoof, Joost, and Froukje van Dijken

2008 The Historical Turf Farms of Iceland: Architecture, Building Technology and the Indoor Environment. Building and Environment 43(6):1023-1030.

Vebæk, Christen Leif

1943 Inland Farms in the Norse East Settlement. Meddelelser om Grønland 90(1):1-120.

1968 Besigtigelser af nordboruiner 1945-62 i den sydlige Østerbygd (unpublished report in the Archives of National Museum of Denmark, jr. nr. 33-325). Copenhagen: National Museum of Denmark.

1991 Hunting on Land and at Sea and Fishing in Medieval Norse Greenland. Acta Borealia 8(1): 5-12.

Vésteinsson, Orri

2010 Parishes and Communities in Norse Greenland. Journal of the North Atlantic 2(sp2):138-150.
2013 What is in a Booth? Material Symbolism at Icelandic Assembly Sites. Journal of the North Atlantic 2012(sp5):111-124.

Vésteinsson, Orri, Thomas H. McGovern, and Christian Keller

2002 Enduring Impacts: Social and Environmental Aspects of Viking Age Settlement in Iceland and Greenland. Archaeologia Islandica 2:98-136.

Wallace, Birgitta

1991 L'Anse aux Meadows: Gateway to Vinland. Acta Archaeologica 61:166-197.

2003 The Norse in Newfoundland: L'Anse aux Meadows and Vinland. Newfoundland and Labrador Studies 19(1):5-43.

2006 Westward Vikings: The Saga of L'Anse aux Meadows. St. John's: Historic Sites Association of Newfoundland and Labrador.

2009 L'Anse Aux Meadows, Leif Eriksson's Home in Vinland. Journal of the North Atlantic 2(sp2): 114-125.

Wickler, Stephen

2016a The Centrality of Small Islands in Arctic Norway from the Viking Age to Recent Historic Period. The Journal of Island and Coastal Archaeology 11(2):171-194.

2016b Medieval Shipwrecks from North Norway and their Contribution to Understanding Maritime Interaction and Trade. International Journal of Nautical Archaeology 45(1):59-76.

Witting, Lars, and Erik W. Born

2005 An Assessment of Greenland Walrus Populations. ICES Journal of Marine Science 62: 266-284.

Wormskiold, M.

1814 Gammelt og Nyt om Grönlands, Viinlands, og nogle fleere Forfædrene kiendte Landes Beliggenhed Det skandinaviske Litteraturselskabs Skrifter Tiende Aargang:298-403. 